\title{
ANAYASA MAHKEMESİ KARARLARINDA MAKUL SÜREDE YARGILANMA HAKKININ İHLALI
}

İsmail ŞAHİ*

\section{ÖZET}

Adil yargılanma hakkının bir cüzü olan makul sürede yargılanma hakkı, ulusal ve uluslararası düzenlemeler ile Avrupa İnsan Hakları Mahkemesi(AİHM) ve Anayasa Mahkemesinin çok sayıda içtihadına konu edilen ve davaların mümkün olan en kısa sürede neticelendirilmesini amaçlayan temel bir insan hakkıdır. Bu hakkı ihlal edilen kişiler için etkili bir iç hukuk yolu olarak 2010 yılında yapılan Anayasa değişikliği ile bireysel başvuru imkânı getirilmiştir. Anayasa Mahkemesi de başvuruları kabul etmeye başladığından bu yana makul sürede yargılanma hakkına dair çok sayıda karar vermiştir. Bu kararlarda, Avrupa İnsan Hakları Mahkemesinin yerleşmiş içtihatları gözetilerek davanın karmaşıklığı, tarafların tutumu, yetkili makamların tutumu ve başvurucunun davanın hızla sonuçlandırılmasındaki menfaatinin niteliği ölçütlerinin kullanılmasıyla ihlal değerlendirmesi yapıldığı anlaşılmaktadır. Mahkemece bu değerlendirme neticesinde makul sürede yargılanma hakkının ihlaline hükmedilen hallerde talep bulunması şartıyla, davanın niteliği, geçen süre, taraf sayısı gibi ölçütler çerçevesinde de manevi tazminata hükmedilmektedir. Anayasa Mahkemesi ve AİHM'nin içtihatları incelendiğinde makul yargılama süresi aşılmasına rağmen, başvurucunun yargılama sürecindeki kusur ya da ihmali, yargılama mercilerinin iş yükünde tahmin edilemeyen krize dayalı geçici bir yoğunluk, deprem ve sel gibi mücbir sebepler ve üçüncü kişinin davranışı nedeniyle yargılamanın uzaması hallerinde ise devletin sorumlu tutulmadığı görülmektedir. 15 Temmuz darbe girişimi nedeniyle yargının iş yükünün olağanüstü artışı ve bazı yargı mensupları ile personelinin meslekten çıkarılmaları davaların görülme süresini uzatacaktır. Ancak, devletin bu durum karşısında gerekli tedbirleri alması nedeniyle, Anayasa Mahkemesince makul sürenin tespitinde darbe teşebbüsünün olumsuz etkisinin gözetilmesi gerekecektir.

Anahtar Kelimeler: Anayasa Mahkemesi, Bireysel Başvuru, Makul Sürede Yargılanma Hakkı, Manevi Tazminat, 15 Temmuz Darbe Girişimi

* Adalet Bakanlığı, ismail.sahin.ab@adalet.gov.tr

(Geliş Tarihi: 12.06.2018 - Kabul Tarihi: 09.10.2018) 


\title{
VIOLATION OF THE RIGHT TO A TRIAL WITHIN A REASONABLE TIME IN DECISIONS OF THE TURKISH CONSTITUTIONAL COURT
}

\begin{abstract}
The right to trial within a reasonable time, which is a part of the right to a fair trial, is one of the fundamental human rights which has been discussed in several national and international regulations, and numerous judicial precedents of European Court of Human Rights (ECHR) and the Constitutional Court, aiming at finalization of cases in the shortest time possible. Through the constitutional amendment package adopted in 2010, the right to individual application was introduced as a form of effective domestic remedy for those whose rights are infringed. Since it started receiving individual applications, the Constitutional Court has taken plenty of decisions regarding the right to trial within a reasonable time. It is understood that the evaluation of infringement is carried out using the criteria composed of the complexity of the case, attitudes of parties, attitudes of authorities, nature of the interest of the applicant in finalization of the case in a reasonable time, as well as taking into consideration the established case law of European Court of Human Rights (ECHR). As the result of the evaluation of the judicial precedents, the Court decides, if demanded by the applicant, on non-pecuniary damages in accordance with the criteria like the nature of the case, elapsed time, number of parties etc. in the cases where it is resolved that the right to trial within a reasonable time has been infringed. Examination over the decisions of Constitutional Court and the ECHR revealed that it is possible that the state is not deemed accountable in cases where the judgment process exceeds the reasonable time due to faults and negligence of the applicant throughout trials, temporary congestion of judiciary's workload based on unpredictable crisis, force majeure like earthquakes and floods and behaviors of third parties. As a result of the failed coup attempt at $15^{\text {th }}$ of July, an extraordinary rise in the workload of judiciary and dismissals of some members of judiciary and judicial personnel will increase the duration of proceedings. However, together with the required measures taken by the State, it is deemed that the negative effects of coup attempt on reasonable time will be anticipated by the Constitutional Court's determinations.
\end{abstract}

Key Words: Constitutional Court, Individual Application, Right to Trial Within a Reasonable Time, Immaterial Compensation, 15 July Coup Attempt 


\section{GíRİ̧}

Bireysel başvuru, 07.05.2010 tarihli ve 5982 sayılı Kanunla yapılan Anayasa değişikliği ile hukukumuza girmiş, 23.09.2012 tarihinden itibaren de Anayasa Mahkemesi bireysel başvuruları kabul etmeye başlamıştır. Bu başvurularda, adil yargılanma ve onun temel bir cüzü olan makul sürede yargılanma hakkının ihlalinden yakınılan dosya sayısının önemli bir yer tuttuğu görülmektedir. Hatta Mahkemede oluşan terakümün giderilmesi için bu konudaki derdest başvurularda Mahkemece kabul edilemezlik kararı verilmesi ile müracaat üzerine dosyaların İnsan Hakları Tazminat Komisyonu tarafından incelenmesine dair kanuni düzenleme getirilmiştir ${ }^{1}$. Bu tespitten yola çıkılarak, uzun yargılamalardan kaynaklı zararların devletçe giderilmesi talebine dair bireysel başvuruların temelinde yer alan sorunlar ile Anayasa Mahkemesinin bu başvuruları inceleme usulü ve kararlarında gözettiği ölçütlerin tespitinin, makul sürede yargılanma hakkına yönelik ihlallerin azaltılmasına katkı sağlayacağı düşüncesiyle çalışma konumuz belirlenmiştir.

Çalışmamızda öncelikle ilgili ulusal ve uluslararası normlardan hareketle makul sürede yargılanma hakkına dair genel bilgilere yer verilecektir. Akabinde makul sürede yargılanma hakkının ihlali nedeniyle yapılan bireysel başvurular üzerine Anayasa Mahkemesince verilen kararlar temelinde bir inceleme yapılacaktır. İncelemede, bu kararlar ile AİHM’nin yerleşmiş içtihatları gözetilerek farklı yargı kollarına göre hakkın içeriği, genel olarak bireysel başvuruların kabul edilebilirlik ölçütleri ve makul sürede yargılanma hakkının ihlali konulu başvurulardaki istisnaları, makul süre değerlendirilmesinde dikkate alınan ölçütler ile makul sürenin başlangıç ve bitiş tarihleri üzerinde durulacaktır.

Son olarak ise, devletin sorumluluğunun niteliği ve hükmedilen tazminat miktarları ile devletin sorumluluğunun istisnaları ve bilhassa 15 Temmuz darbe girişiminin yargılamalarda yol açacağı muhtemel gecikmelerin makul sürede yargılanma hakkı açısından etkisi değerlendirilerek çalışmamız neticelendirilecektir.

6384 sayılı Avrupa İnsan Hakları Mahkemesine Yapılmış Bazı Başvuruların Tazminat Ödenmek Suretiyle Çözümüne Dair Kanunun Geçici 2 nci Maddesi. 


\section{MAKUL SÜREDE YARGILANMA HAKKI VE BU HAKKIN İHLALİNE DAYALI BİREYSEL BAŞVURULAR \\ A- MAKUL SÜREDE YARGILANMA HAKKI}

Adil yargılanma hakkının bir görünümü olan makul sürede yargılanma hakkının Anayasal veya yasal bir tanımı bulunmamakla birlikte bu hakka ulusal ve uluslararası düzenlemelerde yer verilmiştir. Ayrıca, makul sürede yargılanma hakkı AİHM ve Anayasa Mahkemesinin çok sayıda içtihadına konu olmuştur.

Avrupa İnsan Hakları Sözleşmesinin(AİHS) adil yargılanma hakkı başlıklı $6 \mathrm{ncı}$ maddesinde adil yargılama kavramına dair hak ve ilkelerin bir kısmı açıkça belirtilirken bazıları ise AİHM’nin yorumlarıyla geliştirilmiştir². Makul sürede yargılanma hakkı, maddenin birinci fikrasında açıç̧a zikredilen ve adil yargılanma hakkını oluşturan temel haklardan biridir. Düzenlemeye göre, herkes davasının, medeni hak ve yükümlülükleriyle ilgili uyuşmazlıklar ya da cezai alanda kendisine yöneltilen suçlamaların esası konusunda karar verecek olan, yasayla kurulmuş, bağımsız ve tarafsız bir mahkeme tarafından, aleni ve makul bir süre içinde görülmesini isteme hakkına sahiptir.

Hukukumuzda ise adil yargılanma hakkına ilişkin temel norm, Anayasamızın $36 \mathrm{nc1}$ maddesinde yer verilen "Herkes, meşru vasıta ve yollardan faydalanmak suretiyle yargı mercileri önünde davacı veya davalı olarak iddia ve savunma ile adil yargılanma hakkına sahiptir." düzenlemesidir. Adil yargılanma hakkının bir görünümü olan makul sürede yargılanma hakkı ise Anayasamızın 141 inci maddesinin dördüncü fikrasinda "Davaların en az giderle ve mümkün olan süratle sonuçlandırılması, yargının görevidir.” şeklinde açıkça düzenlenmiştir.

Bu uluslararası ve anayasal normların dışında bilhassa usul kanunlarımızda makul sürede yargılanma hakkının sağlanması amacıyla bazı düzenlemelere yer verilmiştir. Bu kapsamda 6100 sayılı Hukuk Muhakemeleri Kanununun "Usul ekonomisi ilkesi” başlıklı 30 uncu maddesinde hâkimin, yargıla-

\footnotetext{
2 İnceoğlu, Sibel (Editör) (2013) İnsan Hakları Avrupa Sözleşmesi ve Anayasa(Anayasa Mahkemesine Bireysel Başvuru Kapsamında Bir İnceleme), 1. Baskı, Ankara, Şen Matbaa, s. 209.
} 
manın makul süre içinde ve düzenli bir biçimde yürütülmesini sağlamakla yükümlü olduğu belirtilmektedir. Yine aynı Kanunun 320 nci maddesinde yer verilen duruşmalar arasındaki sürenin bir aydan daha uzun olamayacağı kuralı da doğrudan makul sürede yargılanma hakkının korunmasına yönelik bir hükümdür.

5271 sayılı Ceza Muhakemesi Kanununun(CMK) 190 ınc1 maddesinde ise duruşmaya ara verilmeksizin devam edilerek hüküm verilmesi kural olarak belirtildikten sonra, sadece zorunlu hâllerde ancak davanın makul sürede sonuçlandırılmasını olanaklı kılacak surette duruşmaya ara verilebileceği düzenlenmiştir. Bu hükümle ceza yargılamasının maddi gerçeğe ulaşma amacı ile makul sürede yargılanma hakkı arasında bir denge gözetilmiştir. CMK'nın 31, 178 ve $206 \mathrm{nc}$ maddelerinde de benzer nitelikteki düzenlemelere yer verilmiştir. Mezkûr hükümlerde, sadece davanın uzatılması amacını taşıyan bir kısım taleplerin reddedileceği belirtilmektedir.

Sadece kovuşturma aşamasında değil ceza muhakemesinin tüm aşamalarında makul sürede yargılanma hakkına riayet edilmelidir. Aşağıda ayrıntılı olarak inceleneceği üzere ceza davalarında makul sürenin başlangıcı olarak çoğunlukla soruşturma aşamasında kişinin suç isnadıyla karşılaştığı an kabul edildiğinden, bu aşamanın da makul sürede neticelendirilmesi gerekmektedir. $\mathrm{Bu}$ nedenle CMK'da soruşturma veya kovuşturma aşamalarındaki bazı koruma tedbirleri için kısa sürelere yer verilmesiyle kişi hak ve hürriyetlerinin korunmasının yanında, işlemlerin biran evvel sonuçlandırılmasının ve böylece makul sürede yargılanma hakkının korunmasının amaçlandığı da söylenebilir.

İstinaf ve temyiz incelemelerinin de makul sürede neticelendirilmesi gerekmektedir. Bölge adliye mahkemelerince ilk derece mahkemesi kararındaki hukuka aykırılığın düzeltilerek istinaf başvurusunun esastan reddine karar verilmesi ile 303 üncü maddesinde yer verilen Yargıtay tarafından bozma kararı verilmeksizin hukuka aykırıllı̆ın giderilmesine dair hükümler, yargılamaların sürüncemede kalmamasını amaçlayan hükümlerdir. Benzer hükümlere hukuk davaları ve idari davalar için Hukuk Muhakemeleri Kanununun 352 ve 370 nci maddeleri ile 2577 sayılı İdari Yargılama Usulü Kanununun 49 uncu maddesinde de yer verilmiştir. 
Anılan düzenlemeler dışında, Yargıtay ${ }^{3}$ ve Danıştay ${ }^{4}$ ın, içtihatlarıyla da makul sürede yargılama hakkının korunmasını amaçladığı anlaşılmaktadır.

Makul sürede yargılanma hakkının teminine dair bu hükümlerle kişilerin haklarına bir an evvel ulaşmalarının sağlanması ve uzun yargılamaların yol açacağı maddi ve manevi kayıpların önlenmesi amaçlanmaktadır. Bu itibarla makul süre değerlendirmelerinde, başvurucunun asıl davada haklı olup olmadığına bakılmamakta, diğer bir deyişle davanın neticesine önem verilmemektedir $^{5}$. Ceza davasında sanığın beraat etmesi veya mahkûm olması arasında fark olmadığı gibi davanın zamanaşımı nedeniyle düşmesi de makul sürede yargılanma hakkının ihlalini ortadan kaldırmayacaktır ${ }^{6}$.

3 Yargitay Ceza Genel Kurulu E: 2011/5.MD-137, K: 2013/58, T: 19.02.2013. “...Avrupa İnsan Hakları Sözleşmesinin 6. maddesinin; "kişinin makul sürede yargılanma hakkı olduğuna" ilişkin normu da dikkate alındığında, temyiz davasında işin esasına girilerek dosyadaki tüm bilgi ve belgelerin incelenip değerlendirilmesinin esas olduğu kabul edilmelidir. Temyiz incelemesi sırasında kanun koyucu tarafından incelemeye konu suçlara ilişkin değişiklik yapılması durumunda, temyiz merciince sonradan yürürlüğe giren kanun nedeniyle lehe kanun hükümlerinin uygulanması yönünde mahkemesince değerlendirme yapılması gerektiği için işin esasına girilmeden bu yönde bozma yapılması mümkün ise de, yürürlüğe giren yeni kanunun açıç̧a lehe olduğunun anlaşıldığı durumlar dışında dosyanın temyiz merciince esastan incelenerek suçun oluşumu, sübutu ve uygulama denetlenip, önceki ve sonraki kanunlar bir bütün halinde değerlendirildikten sonra ortaya çıkan sonuçlar karşılaştırılmak suretiyle lehe kanunun belirlenmesi gerekmektedir. Önceki kanunun lehe olduğu belirlenip, ilk derece mahkemesi uygulamasının isabetli olduğunun anlaşılması durumunda hükmün onanmasına, sonradan yürürlüğe giren kanunun lehe olduğunun belirlenmesi durumunda ise hükmün bu yönden ve varsa diğer bozma nedenleri eklenmek suretiyle bozulmasına karar verilmelidir..."

<https://emsal.yargitay.gov.tr/BilgiBankasiIstemciWeb/> s.e.t. 13.02.2018.

4 Danıştay Onüçüncü Dairesi E: 2016/1621, K: 2016/2257, 08.08.2016. “...Davacı şirketin duruşma istemine gelince, konusuz kaldığı anlaşılan dava ile ilgili olarak duruşma yapılmasının, adil yargılanma hakkının bir unsuru olan makul sürede yargılanma hakkının ihlâline sebebiyet vereceği ve tarafları zarara uğratacak şekilde usul ekonomisine de aykırılık teşkil edeceğinden, duruşma yapılmasına gerek görülmediği gerekçesiyle konusu kalmayan dava hakkında karar verilmesine yer olmadığına karar verilmiş, bu karar davalı idare tarafından temyiz edilmiştir. Konusu kalmayan dava hakkında karar verilmesine yer olmadığına yolundaki temyize konu Bursa 1. İdare Mahkemesi'nin 26.02.2016 tarih ve E:2015/1632, K:2016/172 sayılı kararında, 2577 sayılı İdari Yargılama Usulü Kanunu'nun 49. maddesinin 1. fikrasında sayılan bozma nedenlerinden hiçbirisi bulunmadığından, temyiz istemi yerinde görülmeyerek anılan Mahkeme kararının onanmasına...” şeklidedir.(Yayınlanmamış karara UYAP sisteminden erişilmiştir.)

5 Gözübüyük, Şeref/Gölcüklü, Feyyaz (2011) Avrupa İnsan Hakları Sözleşmesi ve Uygulaması, 9. Baskı, Ankara, Turhan Kitabevi, s. 287. ; Ínceoğlu, 209.

6 Tezcan, Durmuş/Erdem, Mustafa Ruhan/Sancakdar, Oğuz(2004) Avrupa İnsan Hakları Sözleşmesi ve Uygulaması, Ankara, Adalet Bakanlığı Eğitim Dairesi Başkanlığı, s. 200. 


\section{B- MAKUL SÜREDE YARGILANMA HAKKININ İHLALİ İDDİA- SIYLA YAPILAN BİREYSEL BAŞVURULAR}

Anayasamızın 148 ve 149 uncu maddelerinin 5982 sayılı Kanunla değiştirilmesiyle kabul edilen bireysel başvuru, temel hak ve özgürlükleri kamu gücü tarafından ihlal edilen bireylerin başvurabilecekleri tali nitelikteki bir yargı yoludur. Mezkûr 148 inci maddenin beşinci fikrası uyarınca, bireysel başvuruya ilişkin esas ve usuller 30.03.2011 tarihli ve 6216 sayılı Anayasa Mahkemesinin Kuruluşu ve Yargılama Usulü Hakkında Kanun'un 45 ila 51 inci maddelerinde düzenlenmiştir. 12.07.2012 tarihli ve 28351 sayılı Resmi Gazetede yayımlanan Anayasa Mahkemesi İçtüzüğünde ise bireysel başvuruda bulunulması ve bu başvuruların incelenmesine dair ayrıntılı hükümlere yer verilmiştir.

30.06.2018 tarihine kadar Anayasa Mahkemesine yapılan bireysel başvuruların (191.371) \%60'ında başvurucuların adil yargılanma haklarının ihlalinden yakındıkları görülmektedir. Yüksek Mahkemece bu yakınmaya dayalı karara bağlanan başvuruların \%76'sında adil yargılanma hakkının ihlaline karar verilmiştir. Ceza, hukuk ya da idari yargılamalarda başvurucuların makul sürede yargılanma haklarının ihlal edildiğine hükmedilen dosya sayısı da bu oranın \% 80'ine karşılık gelmektedir ${ }^{7}$ İ́statistikî verilerden anlaşıldığı üzere makul sürede yargılanma hakkından kaynaklı ihlaller, bireysel başvurular içinde devletin sorumluluğuna hükmedilen en büyük alanı oluşturmaktadır. Bu nedenle aşağıda bu başvuruların kabul edilebilirliği ve makul sürenin tespitinde kullanılan ölçütler, ayrı başlıklar altında ve çalışma kapsamının elverdiği ölçüde ayrintılı olarak incelenecektir.

\section{1- Başvuruların Kabul Edilebilirliğinde Gözetilen Ölçütler}

Anayasa Mahkemesi bireysel başvuruların kabul edilebilirlik ölçütleri çerçevesinde incelenmesinde bir hiyerarşi geliştirmiştir". Bağlayıcı olmasa da Yüksek Mahkemenin bu tercihinin gözetilmesinin fayda sağlayacağı kanaatiyle incelememizi bu doğrultuda gerçekleştireceğiz.

$<$ http://www.anayasa.gov.tr/icsayfalar/istatistikler/pdf/istatistik-30Haziran.pdf> s.e.t. 26.09.2018.

Turan, Hüseyin/Kaplan, Recep (Editör) (2015) Anayasa Mahkemesine Bireysel Başvuru ve Kabul Edilebilirlik Kriterleri, 1. Baskı, Ankara, Anayasa Mahkemesi Yayınları, s.66. 
Bireysel başvuru form ve ekleri bireysel başvuru bürosu aşamasında öncelikle, Anayasa Mahkemesi İçtüzüğünün 66 ncı maddesine göre ön incelemeye tabi tutulmaktadır.

Her aşamada değerlendirilmesi mümkün olsa da başvurunun süresinde yapılıp yapılmadığı hususu da ilk olarak ön inceleme aşamasında incelenmektedir. Bireysel başvurunun, başvuru yollarının tüketildiği tarihten; başvuru yolu öngörülmemişse ihlalin öğrenildiği tarihten itibaren otuz gün içinde yapılması gerekliliği başvurunun usule dair bir kabul edilebilirlik şartıdır. Tüzüğün 59 ve 60 incı maddelerindeki şekil şartlarına uygun olmadığı ve tespit edilen eksikliklerin verilen kesin sürelerde tamamlanmadığ 1 hâller ile başvurunun süresinde yapılmadığının tespit edildiği hallerde başvuru, itiraz yolu açık olmak üzere başraportör tarafından reddedilmektedir. Bu ret kararına yedi gün içinde yapılacak itiraz üzerine Komisyonca verilen karar ise kesindir.

Ön inceleme sonrasında başvurular diğer kabul edilebilirlik şartları açısından değerlendirilmektedir. Bu şartlar, 6216 sayılı Kanunun 48 inci maddesinde düzenlenmiştir. Maddeye göre bireysel başvurunun hakkında kabul edilebilirlik kararı verilebilmesi için başvurunun Kanunun 45 ilâ 47 nci maddelerinde öngörülen şartları taşıması gereklidir. Anayasa Mahkemesinin yetkisine dair kabul edilebilirlik ölçütleri zaman, kişi, konu ve yer bakımından olmak üzere dört başlıkta incelenmektedir:

- Mahkemenin zaman bakımından yetkisi: 6216 sayılı Kanunun Geçici 1 inci maddesinin sekizinci fikrasında yer verilen "Mahkeme, 23/9/2012 tarihinden sonra kesinleşen nihai işlem ve kararlar aleyhine yapılacak bireysel başvuruları inceler." düzenlemesi Anayasa Mahkemesinin zaman bakımından yetkisini düzenlemektedir. Hukuk güvenliği ilkesinin bir sonucu olan bu düzenleme uyarınca mahkeme, zaman bakımından yetkili olup olmadığını başvurunun tüm aşamalarında inceleyebilecektir?.

- Mahkemenin kişi bakımından yetkisi: Başvurucu gerçek ya da tüzel kişinin, ihlale yol açtığı ileri sürülen işlem, eylem ya da ihmal nedeniyle güncel ve

\footnotetext{
9 Turan/Kaplan, s.30.
} 
kişisel bir hakkının doğrudan etkilenmesinin ${ }^{10}$ bireysel başvurunun kabulü açısından zorunlu olması, mahkemenin kişi bakımından yetkisi olarak nitelendirilmektedir ${ }^{11}$.

- Mahkemenin konu bakımından yetkisi: Kamu gücünün ihlaline konu temel hak ve özgürlügün hem Anayasamız hem de AİHS veya buna ek Ülkemizin taraf olduğu protokoller kapsamında yer alması gerekmektedir ${ }^{12}$. Bu şart,

10 Gurbet Ertürk Başvurusu, AYM, Başvuru No: 2014/16741, K.T. 20.7.2017. “...Başvuruya konu yargılama, başvurucunun eşiyle ilgilidir. Başvurucu, eşini temsile yetkili değildir. Vasisi olmadığı için başvurucuyu temsile yetkili olmayan eşin başvuruya konu edilen ve ihlale yol açtığı ileri sürülen kamu gücü eylem veya işleminden ya da ihmalinden dolayı güncel ve kişisel bir hakkının doğrudan etkilenmeyeceği, bu nedenle mağdur statüsü kazanamayacağ açıktır. Diğer bir ifadeyle başvurucunun sadece "eş" sıfatı adil yargılanma hakkı şikâyetleri bakımından ona mağdur statüsü kazandırmaz. Açıklanan nedenlerle başvurunun diğer kabul edilebilirlik koşulları yönünden incelenmeksizin kişi bakımından yetkisizlik nedeniyle kabul edilemez olduğuna karar verilmesi gerekir...”

$<$ https://kararlarbilgibankasi.anayasa.gov.tr/> s.e.t. 05.03.2018.

Türk Pediatrik Onkoloji Grubu Derneği Başvurusu, , AYM, Başvuru No: 2012/95, 25.12.2012. “...Amacı çocuk onkolojisi alanında tıbbi kaliteyi artırmak olan ve yalnızca üyelerinin durumlarını etkileyen başvuru konusu yasama işleminin mağduru olmayan derneğin, bu işlem aleyhine bireysel başvuru yapma hakkı bulunmamaktadır. Açıklanan nedenlerle, özel hukuk tüzel kişisi olan başvurucu Derneğin mağdur sıfatı taşımadığı anlaşıldığından başvurunun, diğer kabul edilebilirlik şartları yönünden incelenmeksizin "kişi yönünden yetkisizlik" nedeniyle kabul edilemez olduğuna karar verilmesi gerekir..." < https://kararlarbilgibankasi.anayasa.gov.tr/> s.e.t. 05.03.2018. Büğdüz Köyü Muhtarlığı Başvurusu, AYM, Başvuru No: 2012/22, K.T. 25.12.2012. “...Bireysel başvuru, kamu gücünün kullanılmasından kaynaklanan hak ihlallerine karşı tanınan bir yol olduğundan kamu tüzel kişilerine bireysel başvuru hakkı tanınması, bu anayasal kurumun hukuki niteliği ile bağdaşmamaktadır.

Anayasa'nın 127. maddesinin birinci fikrası uyarınca yöneticileri doğrudan seçimle işbaşına gelen ve kamu tüzel kişiliğini haiz mahalli idare birimi olan köye, kamu tüzel kişilerinin bireysel başvuru yapamayacaklarını hükme bağlayan 6216 sayılı Kanun'un 46. maddesinin (2) numaralı fikrası uyarınca bireysel başvuru yapma hakkı tanınmamıştır. Açıklanan nedenlerle kamu tüzel kişisi olan başvurucunun bireysel başvuru ehliyeti bulunmadığı anlaşıldığından, başvurunun diğer kabul edilebilirlik şartları yönünden incelenmeksizin "kişi yönünden yetkisizlik" nedeniyle kabul edilemez olduğuna karar verilmesi gerekir..." < https://kararlarbilgibankasi.anayasa.gov.tr/> s.e.t. 05.03.2018.

11 Doğru, Osman (2012) Anayasa Mahkemesine Bireysel Başvuru Rehberi, İstanbul, Legal Yayıncilik, s. 100.

12 Mustafa Ekici Başvurusu, AYM, Başvuru No: 2014/13675, K.T. 08.09.2014. “...AİHS kapsamında korunan siyasi hak, doğrudan yasama organının seçimi ile ilgilidir. Bu bağlamda başvurucunun üyesi olduğunu belirttiği bir siyasi partinin kongresinin hukuka aykırı şekilde yapıldığı yönündeki iddiası yasama organının seçimi ile ilgili olmadığından Anayasa ve AİHS'in ortak koruma alanında yer almamaktadır. Bu nedenle ileri sürülen ihlal iddiasının bireysel başvuru kapsamında incelenmesi mümkün değildir. Açıklanan nedenlerle, başvurucunun başvuru dilekçesinde ifade ettiği şekliyle ihlal edildiğini ileri sürdüğü hususlar, Anayasa ve AİHS ile buna ek Türkiye'nin taraf olduğu protokollerin ortak koruma alanına girmediğinden, başvurunun "konu bakımından yetkisizlik" nedeniyle kabul edilemez olduğuna karar verilmesi gerekir..." <https://kararlarbilgibankasi.anayasa.gov.tr/> s.e.t. 05.03.2018. 
Kanunun 45 inci maddesinin birinci fikrasında "Herkes, Anayasada güvence altına alınmış temel hak ve özgürlüklerinden, Avrupa İnsan Hakları Sözleşmesi ve buna ek Türkiye'nin taraf olduğu protokoller kapsamındaki herhangi birinin kamu gücü tarafından, ihlal edildiği iddiasıyla Anayasa Mahkemesine başvurabilir” şeklinde düzenlenmiştir. Mezkûr hüküm uyarınca Anayasamızda güvence altına alınmasına rağmen AİHS veya ülkemizin taraf olduğu ek protokollerde yer verilmeyen vatandaşlık, barınma vb. bazı ekonomik ve sosyal hakların ihlali iddiasıyla bireysel başvuru yapılamayacaktır ${ }^{13}$. Bu kabul edilebilirlik ölçütü, mezkûr maddenin üçüncü fikrasında düzenlendiği üzere, başvuruya konu işlemin, yasama işlemi, düzenleyici idari işlem, Anayasa Mahkemesi kararı ve Anayasanın yargı denetimi dışında bıraktığ 1 sair işlemlerden olmamas ${ }^{14}$ gerekliliğini de kapsamaktadır ${ }^{15}$.

- Mahkemenin yer bakımından yetkisi: Anayasa Mahkemesine bireysel başvuru yapılabilmesi için başvuruya konu işlemin Türkiye Cumhuriyeti sınırları içinde gerçekleştirilmiş olması şartı mahkemenin yer bakımından yetkisini oluşturmaktadır ${ }^{16}$.

13 Koç, Muharrem İlhan/Kaplan, Recep (Editör) (2017) Bireysel Başvuru Kabul Edilebilirlik Kriterleri Rehberi, 1. Baskı, Ankara, Anayasa Mahkemesi Yayınları, s. 93.

14 Umut Oran Başvurusu, AYM, Başvuru No: 2014/18926, K.T. 22.01.2015. “...Bireysel başvuru yoluyla doğrudan yasama işlemine değil ancak yasama işleminin uygulanması mahiyetindeki işlem, eylem ve ihmallere karşı başvuru yapılabilecektir. Diğer bir deyişle bir yasama işleminin doğrudan ve soyut olarak Anayasa'ya aykırı olduğu iddiasıyla Anayasa Mahkemesine başvuru yapılamaz. Açıklanan nedenlerle, yasama işlemi aleyhine doğrudan bireysel başvuru yapıldığı anlaşıldığından, başvurunun diğer kabul edilebilirlik şartları yönünden incelenmeksizin 'konu yönünden yetkisizlik' nedeniyle kabul edilemez olduğuna karar verilmesi gerekir..." <https://kararlarbilgibankasi.anayasa.gov.tr/> s.e.t. 05.03.2018.

Nesin Kayserilioğlu (3) Başvurusu, AYM, Başvuru No: 2013/1581, K.T. 16.04.2013. "Başvuru konusu olayda başvurucu, idare mahkemesi hâkimleri hakkında yaptığı şikâyetin işleme konulmaması kararı ve bu karara karşı itirazının HSYK tarafından reddi işlemi aleyhine bireysel başvuruda bulunmuştur. Anayasa'nın 159. maddesinin onuncu fikrası gereğince HSYK'nın bu kararı aleyhine yargı mercilerine başvurulması mümkün değildir. Dolayısıyla başvuru konusu işlem, Anayasa'nın yargı denetimi dışında bıraktığı işlemlerden olduğundan bireysel başvuruya konu olamaz. Açılanan nedenlerle, Anayasa'nın yargı denetimi dışında bıraktığı bir işleme karşı yapıldığı anlaşıldığından başvurunun, diğer kabul edilebilirlik koşulları yönünden incelenmeksizin "konu bakımından yetkisizlik" nedeniyle kabul edilemez olduğuna karar verilmesi gerekir." şeklindedir.

$<$ https://kararlarbilgibankasi.anayasa.gov.tr/> s.e.t. 05.03.2018.

15 Koç/Kaplan, s. 94.

16 Turan/Kaplan, s. 80. ; Doğru, s. 108. 
Kabul edilebilirlik şartlarından bir diğeri ise ihlale neden olduğu ileri sürülen işlem, eylem veya ihmal için kanunda öngörülmüş idari ve yargısal nitelikteki olağan başvuru yollarının tamamının bireysel başvuru yapılmadan önce tüketilmiş olması ${ }^{17}$ gerekliliğidir. Bu şarta 45 inci maddenin ikinci fikrasında yer verilmiştir. AİHS’nin 35 inci maddesinde de bu düzenlemeyle benzer şekilde ilgili devletin iç hukuk yollarının tüketilmesi şartı aranmaktadır. Her iki düzenlemede de ihlallerin giderilmesi açısından daha elverişli olan yolların öncelikle tüketilmesi gerektiği kabulünden hareket edilmiștir.

Başvurunun açıkça dayanaktan yoksun olmaması ise başvurunun esasa dair kabul edilebilirlik kriteridir. Bir ihlalin olmadığının açık olduğu, kanıtlanmamış, karmaşık ve zorlama şikâyetler ve kanun yolu şikâyetleri açıç̧a dayanaktan yoksun kabul edilmektedir ${ }^{18}$. Anayasa Mahkemesi de Hikmet Balabanoğlu'nun 2012/1334 sayılı başvurusunda verdiği kararda bu şartı "6216 sayılı Kanun'un 48. maddesinin (2) numaral fikrasına göre Mahkemece açıkça dayanaktan yoksun başvuruların kabul edilemez olduğuna karar verilebilir. Başvurucunun ihlal iddialarını kanıtlayamadiğı, iddialarının salt kanun yolunda gözetilmesi gereken hususlara ilişkin olduğu, temel haklara yönelik bir müdahalenin olmadığ veya müdahalenin meşru olduğu açık olan başvurular ile karmaşık veya zorlama şikâyetlerden ibaret başvurular açıkça dayanaktan yoksun kabul edilebilir." şeklinde açıklamaktadır ${ }^{19}$.

Anayasa Mahkemesince usule ve esasa dair bu şartlar çerçevesinde başvuruların değerlendirilmesiyle, kabul edilebilirliğine veya kabul edilemezliğine karar verilmektedir.

17 Burhan Seçilir Başvurusu, AYM, Başvuru No: 2014/7274, K.T. 10.06.2015. “...başvurucu tarafından yapılan karar düzeltme başvurusu, Danıştay Onbeşinci Dairesi'nin temyiz üzerine verdiği kararın tebliğini izleyen günden itibaren 15 gün içinde yapılmadığı gerekçesiyle süre aşımı nedeniyle reddedilmiş olup, başvurucunun olağan kanun yollarını usulüne uygun bir şekilde tüketmeden bireysel başvuruda bulunduğu anlaşılmaktadır. Açılklanan nedenlerle, ihlale neden olduğu ileri sürülen karar için kanunda öngörülmüş yargisal başvuru yollarının tamamı bireysel başvuru yapılmadan önce usulüne uygun şekilde tüketilmeden, temel hak ve özgürlüklerin ihlal edildiği iddiasının bireysel başvuru konusu yapıldığı anlaşıldığından, başvurunun, diğer kabul edilebilirlik koşulları yönünden incelenmeksizin "başvuru yollarının tüketilmemiş olması" nedeniyle kabul edilemez olduğuna karar verilmesi gerekir..." şeklindedir.

$<$ https://kararlarbilgibankasi.anayasa.gov.tr/> s.e.t. 05.03.2018.

18 Turan/Kaplan, s. 189.

19 Hikmet Balabanoğlu Başvurusu, AYM, Başvuru No: 2012/1334, K.T. 17.09.2013. <https://kararlarbilgibankasi.anayasa.gov.tr/> s.e.t. 05.03.2018. 


\section{2- Makul Sürede Yargılanma Hakkının İhlali İddiasına Dayalı} Başvuruların Kabul Edilebilirlik Ölçütleri Açısından Değerlendirilmesi

Yukarıda zikredildiği üzere makul sürede yargılanma hakkı hem Anayasamızda hem de AİHS'de güvence altına alınmıştır. Bu nedenle bu hakkın ihlal edildiği iddiasıyla yapılan bireysel başvuruların, 6216 sayılı Kanunun 45 inci maddenin birinci fikrasındaki şartı sağlaması nedeniyle Anayasa Mahkemesince konu bakımından yetkisizlik nedeniyle kabul edilemezlik kararı verilemeyeceği açıktır.

Makul sürede yargılama hakkının ihlal edildiği iddiasını içeren başvurular açısından, kanun yollarının tüketilmesi şartı da aranmamaktadır ${ }^{20}$. Başvuru yollarının tüketilmesi ilkesinin mutlak şekilde uygulanması, temel hak ve özgürlüklerin etkin kullanımını ve korunmasını engelleyecektir. Şöyle ki, hukuk sistemimizde, yargılama faaliyetinin makul sürede gerçekleştirilmesini temin eden, bir başka ifade ile yargılamanın uzamasını önleyici etkiye sahip olan veya yargılamanın makul sürede yapılmaması sonucunda oluşan zararları tespit ve tazmin edici nitelik taşıyan etkin nitelikte bir idari veya yargısal başvuru yoluna yer verilmemiştir.

Makul sürede yargılanma hakkı açısından bir imkân olarak 09.01.2013 tarih ve 6384 sayılı Avrupa İnsan Hakları Mahkemesine Yapılmış Bazı Başvuruların Tazminat Ödenmek Suretiyle Çözümüne Dair Kanun ile ihdas edilen başvuru yolu, sadece AİHM'de ileri sürülen bu tür ihlal iddiaları açısından tüketilmesi gereken bir başvuru yolu olarak kabul edilmekteyken, 25.07.2018 tarihli ve 7145 sayılı Kanunla 6384 sayılı Kanuna eklenen Geçici 2 nci madde ile Anayasa Mahkemesinde derdest olan bireysel başvuruların Komisyonca incelenmesi yolu açılmıştır. Ancak bu hüküm Kanunun yürürlüğe girdiği 31.07.2018 tarihinden sonraki başvuruları kapsamamaktadır. Bu nedenlerle, halen makul sürede yargılama yapma yükümlülügünün yerine getirilmediği iddiası ile Anayasa Mahkemesine bireysel başvuruda bulunulabilmesi, başvuru yollarının tüketilmiş olması kuralının istisnalarından birini teşkil etmektedir. Zira bu durumda başvuru yollarının tüketilmesi şartının aranması, makul sürede yargılama yapma yükümlülüğüne aykırı davranılması nedeniyle meydana gelen sonuçları ortadan kaldırmayacaktır. Aksine, makul olmadığı iddia edilen yargılama faaliyetinin daha da uzamasına ve başvurucu açısından zararın artmasina neden olabilecektir.

20 Çelik, Abdullah (2014) Adil Yargılanma Hakkı Rehberi, Ankara, Anayasa Mahkemesi Yayınları, s. 73. ; Turan/Kaplan, s. 110. 
Devam eden yargılamalarda, makul sürenin aşıldığı iddiasında bulunulması her zaman mümkün olduğundan otuz günlük sürede başvurulması şartı aranmayacaktır.

İhlale yol açtığı ileri sürülen işlem, eylem ya da ihmal nedeniyle başvurucunun güncel ve kişisel bir hakkının doğrudan etkilenmesi şartı ise makul sürenin ihlali nedenine dayalı başvurular açısından da geçerlidir.

Makul sürede yargılanma hakkının ihlali iddiasını taşıyan başvuruların Anayasa Mahkemesinin zaman bakımından yetkisinin başlangıcı olan 23.09.2012 tarihinden sonra yapılmış olması gereklidir. Bu gerekliliği taşıyan başvurularda belirtilen tarihten önce başlayan sürelerin makul sürenin hesabında dikkate alınıp alınamayacağı ise aşağıda ayrıntılı olarak incelenecektir.

\section{C- MAKUL SÜRENIN TESPITINDE GÖZETILEN KRITTERLER}

AİHM sekiz yll ve üzerindeki süreleri neredeyse her zaman makul sürede yargılanma hakkının ihlali saymaktadır. Özel şartları nedeniyle altı ve yedi yıllık bazı yargılamaları makul sürede gören mahkeme yine özel şartları nedeniyle iki yıllık süreyi dahi makul süreye aykırı bulabilmektedir ${ }^{21}$. Mahkeme içtihatlarından her davanın kendi özellikleri çerçevesinde değerlendirildiği anlaşılmaktadır. Anayasa Mahkemesi de makul sürede yargılama yapılıp yapılmadığına karar verirken her davanın kendine özgü niteliklerini AİHM’nin de esas aldığı bazı ölçütler çerçevesinde değerlendirmektedir. Bu ölçütler davanın karmaşıklığı, tarafların tutumu, yetkili makamların tutumu ve başvurucunun davanın hızla sonuçlandırılmasındaki menfaatinin niteliği şeklinde sayılabilecektir. Gerek AİHM gerekse Anayasa Mahkemesi kararlarında bu ölçütlere dair önemli ve yerleşmiş ilkeler yer almaktadır. Ancak belirtilen ölçütlerden hiçbiri makul süre değerlendirmesinde tek başına belirleyici değildir. Yargılama sürecindeki tüm gecikme nedenlerinin ayrı ayrı tespiti ile toplam süreye etkisi değerlendirilerek, hangi unsurun yargılamanın gecikmesi açısından daha etkili olduğu saptanmalidir ${ }^{22}$.

${ }^{21}$ İnceoğlu, Sibel (2007) Adil Yargılanma Hakkı ve Yargı Etiği, 1. Baskı, Ankara, Şen Matbaa, s. 113.

22 Güher Ergün ve Diğerleri Başvurusu, AYM, Başvuru No: 2012/13, K.T. 02.07.2013. $<$ https://kararlarbilgibankasi.anayasa.gov.tr/> s.e.t. 05.03.2018. 


\section{1-Davanın Karmaşıklı̆̆ı}

Her somut davanın kendine özgü bazı özellikleri vardır. Bunlar davanın konusu, taraf sayısı, tabi olduğu kanun yolları gibi hukuki veya maddi farklılıklara ilişkindir. Bu nedenle yargılamalar aynı türden olsa dahi bunların tamamında geçerli olacak makul bir süre tespit edilmesi mümkün değildir. Bazı davaların çözümü oldukça basitken bazılarının ki ise ziyadesiyle zordur. Bu nedenle, Anayasa Mahkemesi aşağıda incelenecek ölçütlerden yola çıkarak davanın karmaşık olup olmadığını araştırmakta ve davanın çözümünün zor olduğu hallerde yargılamaların neticelendirilmesindeki makul süreyi, kolay olanlara nispeten daha uzun belirlemektedir.

AİHM ve Anayasa Mahkemesi yargılamanın karmaşıklığını değerlendirirken davanın hem hukuki hem de maddi açıdan bütün yönlerini ele almakta; hukuki meselenin çözümündeki güçlük, delillerin toplanmasında karşılaşılan engeller, maddi olayların karmaşıklığı, sanıkların ya da isnat edilen suçların veya tanıkların sayısı, davanın uluslararası unsurları, bilirkişi deliline duyulan ihtiyaç, yazılı delillerin hacmi gibi birçok unsuru incelemektedir ${ }^{23}$. Ancak, sayılan bu unsurlar nedeniyle karmaşık olduğu kabul edilen davanın uzamasında, haklı görülemeyecek başka sebeplerin de bulunması halinde davanın karmaşıklığı haklı bir gerekçe olmaktan çıkmaktadır²4.

Davanın karmaşıklığı ölçütü adaletin yerine getirilmesi ilkesi ile dengelenmektedir ${ }^{25}$. AİHM bir kararında, davanın karmaşıklığı ile ilgili olarak, davadaki sanık sayısı, suçun ekonomik boyutu, bilirkişi raporuna ihtiyaç duyulmas1 ${ }^{26}$ gibi nedenlerle yedi yıl yirmi yedi gün süren yargılama süresinin makul

\footnotetext{
İnceoğlu, s. 280.

24 Turan, Hüseyin (2012) “Avrupa İnsan Hakları Mahkemesi İçtihatlarında Makul Sürede Yargılanma Hakkı” Türkiye Adalet Akademisi Dergisi, Yıl:3, S:11, s.61.

25 İnceoğlu, Adil Yargılanma Hakkı ve Yarg1 Etiği, s. 118.

26 Abdullah Seyrek Başvurusu, AYM, Başvuru No: 2014/7206, K.T. 26.10.2017. “...Başvuruya konu yargılama süreci incelendiğinde, dava iki dereceli bir yargılama sisteminde toplam 4 yıl 6 ay sürmüştür. Çok sayıda yıla ait genel kurul kararının iptali talebini içerir davada apartmana ait defter ve hesaplar üzerinde bilirkişi incelemesi yapılmasının zorunluluğu, başvurucunun daha sonra açmış olduğu davanın mevcut dava ile birleşmesi ve temyiz aşamasında apartmana ait defterler üzerinde inceleme yapılmasına duyulan ihtiyaç nedeniyle defterlerin apartman yönetiminden istenmesinde geçen süre gözönünde tutulduğunda yargılama sürecinin bütünü içinde başvurucunun haklarını ihlal edecek bir gecikme olmadığı sonucuna ulaşılmıştır..." <https://kararlarbilgibankasi.anayasa.gov.tr/> s.e.t. 05.03.2018.
} 
olduğunu belirtmiştir ${ }^{27}$. Anayasa Mahkemesince de makul sürede yargılanma hakkının ihlali iddiasıyla yapılan bir başvurunun değerlendirilmesinde, başvurucuya suç isnat edildiği tarih ile bireysel başvurunun karara bağlandığı tarih arasında geçen yaklaşık yedi yıl üç aylık yargılama süresinin makul olduğu, yargılama faaliyetlerinde hareketsiz kalınan bir dönemin bulunmadığı, yargı mercilerine atfedilebilecek bir kusurun olmadığı ve gerekli özenin gösterildiği kabul edilerek başvurucunun makul sürede yargılanma hakkının ihlal edilmediğine karar verilmiştir ${ }^{28}$. Benzer şekilde, Mahkeme İbrahim Halil Yahli’nin 2014/176 sayılı başvurusunda verdiği kararda da üç sanık hakkında terör örgütü propagandası yapmak suçundan yapılan dört yıl altı aylık yargılama süresini makul bulmuştur ${ }^{29}$.

Mahkeme, 2013/2995 sayılı başvuru üzerine verdiği 20.02.2014 tarihli kararında ise sulh hukuk mahkemesinde görülen taşınmazın aynına ilişkin bir

27 https://hudoc.echr.coe.int/tur\#\{"fulltext":["|"63964/00।"'],"documentcollectionid2": ["GRANDCHAMBER","CHAMBER"],"itemid":["001-77575"]\} s.e.t. 27/12/2017) (M.A.T./Türkiye,AİHM, Başvuru No: 63964/00, K.T. 19.1.2007. \$ 40) s.e.t. 13.02.2018. Murat Öztürk Başvurusu, AYM, Başvuru No: 2014/2454, K.T.04.11.2014. <https://kararlar bilgibankasi.anayasa.gov.tr/> s.e.t. 05.03.2018.

29 “...Başvuru konusu olayda, başvurucu hakkında kamu davasının açıldığı 25/9/2006 tarihinden itibaren Mahkemece 22/11/2007 tarihinde verilen karar tarihine kadar, bir yll bir ay yirmi yedi gün yargılamanın devam ettiği, başvurucunun savunmasının ilk olarak 1/2/2007 tarihinde alındığı ve yargılamadan anılan tarihte haberdar olduğu anlaşılmıştır. Mahkemece 22/11/2007 tarihinde verilen kararın temyizi üzerine Yargıtay 9. Ceza Dairesince hükmün onandığı 11/4/2011 tarihine kadar üç yıl dört ay yargılama sürecinin devam ettiği, bu şekilde başvurucu hakkında kamu davasının açıldığı tarihten itibaren yargılamanın toplam dört yıl altı ay sürdüğü, başvurucunun savunmasının alındığı tarihten itibaren ise dört yıl iki aylık süre sonunda yargılamanın sonuçlandığı anlaşılmıştır. Yargılama süresinin makul olup olmadığının incelenmesi sırasında göz önünde bulundurulması gereken; davadaki sanık sayısı, davanın karmaşıklığı, atılı suçların vasıf ve mahiyeti, yargılamanın kaç dereceli olduğu gibi unsurlar bir bütün olarak değerlendirildiğinde yargılama dosyasında toplam üç sanığın yargılandığı, 3713 sayılı Kanun'a dayalı olarak "terör örgütü propagandası yapmak" suçundan yargılama yapıldığı, isnat olunan suçun niteliği dikkate alındığında davanın karmaşık nitelikte olduğu, yargılama faaliyetlerinde yargılama makamlarınca hareketsiz kalınan bir dönemin bulunmadığı, yargı mercilerine atfedilebilecek bir kusurun olmadığı ve gerekli özenin gösterildiği dolayısıyla somut başvuru bakımından yargılama süresinin makul olduğu, Adalet Bakanlığı İnsan Hakları Tazminat Komisyonu Başkanlığı ve Ankara Bölge İdare Mahkemesi 3. Kurulunun kararlarının yerinde olduğu ve başvurucunun makul sürede yargılanma hakkına yönelik bir ihlalin olmadığı sonucuna varılmıştır. Açılanan nedenlerle, Anayasa'nın 36. maddesinde güvence altına alınan adil yargılanma hakkının ihlal edilmediğine karar verilmesi gerekir..." <https://kararlarbilgibankasi.anayasa.gov.tr/> s.e.t. 05.03.2018. 
davada, davanın keşif ve bilirkişi incelemesi gibi usul işlemlerini gerektirmesine bağlı olarak karmaşık bir niteliğe sahip olduğu ve başvuru konusu olayda uygulanması gereken usul hükümleri nazara alındığında, söz konusu iki dereceli yargılamada geçen üç yıl iki aylık yargılama süresinin makul süreyi aşmadığına hükmetmiştir ${ }^{30}$.

\section{2- Başvurucunun Tutumu}

Anayasa Mahkemesi, başvurucunun kendi kusurundan kaynaklı gecikmeleri dikkate alarak makul sürede yargılanma hakkının ihlal edilmediği sonucuna ulaşabilmektedir. Başvurucu vekilinin çok sayıda mazeret vermesi, bilirkişi raporu veya keşif için gerekli giderleri süresinde yatırmaması, çok sayıda dilekçe vermesi ${ }^{31}$ gibi haller başvurucudan kaynaklanan tipik kusurlardır. Ancak, başvurucunun kanunlardan kaynaklı haklarından istifade etmesinin bu kapsamda değerlendirilemeyeceği gözden kaçırılmamalıdır ${ }^{32}$.

Mahkeme, 2014/7677 sayılı başvuru üzerine verdiği kararda beş yılı aşkın bir süredir ilk derece mahkemesinde devam eden davada, başvurucu ve vekilinin duruşmalara katılım ve ara kararların yerine getirilmesinde gerekli özeni göstermediğini, bilirkişi masrafının bir yıl on ay sonra yatırıldığını ayrıca bir kısım duruşmalara katılım sağlanmaması nedeniyle yargılamanın beş ay uzamasına neden olunduğunu, başvurucuya atfedilebilecek kusur ve davranışlar

30 “...Başvurunun değerlendirilmesi neticesinde, başvuruya konu yargılamanın iki adet taşınmaza ilişkin sınır ihtilafı nedeniyle yetkili sulh hukuk mahkemesinde görülen bir mülkiyet uyuşmazlığı olduğu, iki davalı aleyhine açılan davada iki defa taşınmaz başında keşif icra edilerek bilirkişi raporu temin edildiği, yargılama kapsamında uyuşmazlığa ilişkin olarak ilk derece mahkemesince iki defa karar verildiği, belirtilen kararların iki defa Yargıtay denetiminden geçtiği, bu inceleme süreçlerinin toplamda üç yıl altı günlük bir süreyi kapsadığı, yarg1lamanın özellikle taşınmazın aynına ilişkin bir ihtilaf olması nedeniyle, keşif ve bilirkişi incelemesi gibi usul işlemlerini gerektirmesine bağlı olarak karmaşık bir niteliğe sahip olduğu ve başvuru konusu olayda uygulanması gereken usul hükümleri nazara alındığında, söz konusu iki dereceli yargılama prosedüründe geçen üç yıllık yargılama süresinin makul süreyi aşmadığı ve başvuruya konu uyuşmazlığın karara bağlanmasının yargılama makamlarının tutumu nedeniyle geciktirildiğine dair bir bulgu saptanmadığı anlaşılmaktadır. Yukarıda açıklanan nedenlerle, başvurucunun tarafı olduğu uyuşmazlığa ilişkin yargılama süresinin makul süreyi aşmadığı ve başvuruya konu uyuşmazlığın karara bağlanmasının yargılama makamlarının tutumu nedeniyle geciktirildiğine dair bir bulgu saptanmadığı anlaşılmakla, Anayasa'nın 36. maddesinde güvence altına alınan makul sürede yargılanma hakkının ihlal edilmediğine karar verilmesi gerekir...”

(https://kararlarbilgibankasi.anayasa.gov.tr/) s.e.t. 05/03/2018)

31 Tezcan/Erdem/Sancakdar, s. 199.

32 İnceoğlu, Adil Yargılanma Hakkı ve Yargı Etiği, s. 119.; Turan, s. 62. 
nedeniyle yargılamanın toplam iki yıl üç ay uzadığını tespit ederek makul sürede yargılanma hakkının ihlal edilmediğine karar vermiştir ${ }^{33}$.

\section{3- Yetkili Makamlarmn Tutumu ve Yapısal Sorunlar}

Adli veya idari makamların yargılamanın uzaması sonucunu doğuracak kusurlu davranışları veya ihmalleri, ihlal kararı verilmesine yol açabilmektedir. Bu kusur ve ihmallere: yargılamada dosyanın müteaddit defa tetkike alınması, hatalı şekilde bekletici mesele kararı verilmesi, gerekçeli kararların geç yazılması, hatalı olarak görevsizlik veya yetkisizlik ya da birleştirme kararları verilmesi, soruşturmaların etkin yürütülmemesi, dosyanın kanun yolu incelemesine geç gönderilmesi gibi çok sayıda örnek verilebilir.

Sadece yargı makamlarının değil devletin kamu gücü kullanan tüm organlarının kusur veya ihmallerinin olup olmadığı üzerinde durulmalıdır. Zira Anayasa'nın $36 \mathrm{nc}$ maddesi ve AİHS’nin $6 \mathrm{ncı}$ maddesiyle devlete, davaları makul bir süre içinde karara bağlama yükümlülüğü de dâhil olmak üzere adil yargılama koşullarını yerine getirebilecek bir hukuk düzeni kurma sorumluluğu yüklenmektedir ${ }^{34}$.

33 “...Makul sürede yargılanma hakkına ilişkin olarak yapılan değerlendirmede önemli bir ölçüt olan başvurucunun davanın hızla sonuçlandırılmasındaki menfaatinin niteliği kriteri çerçevesinde, gerek bireylerin ekonomik geleceği gerek çalışma barışı açısından arz ettiği önem nazara alındığında, iş uyuşmazlıklarının ivedilikle çözülmesi hususunda yargı organlarının özel bir itina göstermesi gerekmektedir. Bu nedenle kanun koyucu iş hukukunun çalışanı koruyucu niteliğini ve iş davalarının özelliklerini dikkate alarak genel mahkemelerin dışında sözlü yargılama usulüne tabi özel bir iş yargılaması sistemi ihdas ederek iş davalarının, konunun uzmanı mahkemelerce mümkün olduğunca hızlı, basit ve ucuz bir biçimde sonuçlandırılmasını amaçlamıştır. Başvuruya konu süreç incelendiğinde; yargılamanın, beş yılı aşkın bir süredir İlk Derece Mahkemesi önünde devam ettiği, başvurucu ve vekilinin duruşmalara katılım ve ara kararların yerine getirilmesinde gerekli özeni göstermediği, bilirkişi masrafının bir yıl on ay sonra yatırıldığı ayrıca bir kısım duruşmalara katılım sağlanmaması nedeniyle yargılamanın beş ay uzamasına neden olunduğu, başvurucuya atfedilebilecek kusur ve davranışlar nedeniyle yargılamanın toplam iki yıl üç ay uzadığı anlaşılmaktadır. Yargılama sürecinin bütünü ve başvurucuya atfedilebilecek tutum ve davranışlar nedeniyle yargılamanın uzama süresi dikkate alındığında, İlk Derece Mahkemesindeki yargılama sürecinde başvurucunun haklarını ihlal edecek bir gecikme olmadığı sonucuna ulaşılmıştır. Açıklanan nedenlerle, Anayasa'nın 36. maddesinin gerektirdiği makul sürede yargılanma hakkının ihlal edildiğinden söz edilemez..."

$<$ https://kararlarbilgibankasi.anayasa.gov.tr/> s.e.t. 05.03.2018.

34 Güher Ergun ve Tosun Tayfun Ergun Başvurusu, AYM, Başvuru No: 2012/13, K.T. 02.07.2013. <https://kararlarbilgibankasi.anayasa.gov.tr/> s.e.t. 05.03.2018. 
Yargılama sürecinin uzamasında yetkili makamlara atfedilecek gecikmeler, yargılamanın süratle sonuçlandırılması hususunda gerekli özenin gösterilmemesinden kaynaklanabileceği gibi, yapısal sorunlar ve organizasyon eksikliğinden de ileri gelebilir. Yargı sisteminin yapısı, iş yükünün ağırlığı, yargıç sayısı gibi haller yapısal sorunların örnekleridir.

Avrupa İnsan Hakları Mahkemesi makul sürede yargılanma hakkının ihlali nedeniyle sistematik olarak aleyhine karar verilen devletlerin yargı mekanizmalarını hızlandıran yapısal çözümler üretmesi gerektiğini birçok kararında belirtmiştir ${ }^{35}$. Devletin, yargılamalardaki terakümü önlemek için organizasyon eksikliklerini, fiziki ve insan kaynağı sorunlarını gidermesi gerekmektedir. Yetkili hâkimin bulunmadığı ve başka hâkimlerin geçici ve ani olarak görevlendirilmeleriyle duruşma ve sair işleri yürüttükleri mahkemelerde yargılamaların süresinin uzadığ sıkça rastlanan bir durumdur.

\section{4- Başvurucunun Davanın Hızla Sonuçlandırılmasındaki Menfaatinin Niteliği}

Tarafların süratle hüküm elde etmelerinde özel bir menfaatlerinin bulunduğu hallerde yargılama mercilerince davanın kısa sürede sonuçlandırılması için özel bir önem gösterilmesi gerektiği AİHM’nin kararlarında vurgulanmaktadır. Bu tür uyuşmazlıkların zamanında neticelendirilmesi etkin hukuki korumanın gerçekleştirilmesi açısından daha da önemlidir. Mahkeme, trafik kazaları nedeniyle oluşan maddi ve manevi tazminat davaları, kan transfüzyonu nedeniyle HIV virüsünün bulaşmasından ötürü açılan tazminat davaları, boşanma davaları, iş ve sosyal güvenlik hukukundan kaynaklı davalar, velayet ve çocukla ilişki kurulması veya soybağının kurulmasını konu alan davalardan doğan uyuşmazlıkların süratle sonuçlandırılmasındaki menfaati üstün görmüştür ${ }^{36}$.

35 Doğru, Osman/Nalbant, Atilla (2012) İnsan Hakları Avrupa Sözleşmesi (Açılama ve Önemli Kararlar), Ankara, Şen Matbaa, s. 636. ; Turan, s. 66.

36 İnceoğlu, s. 278. ; Turan, s. 69. ; Başar, Mükerrem Onur (2011) Avrupa İnsan Hakları Kararları Çerçevesinde Makul Sürede Yargılanma Hakkı, İstanbul, On İki Levha Yayınları, s. 51-54. 
Anayasa Mahkemesi de benzer şekilde iş ve sosyal güvenlik hukukundan kaynaklı davalarda ${ }^{37}$, çalışma gücünü kaybedecek şekilde yaralanmalardan kaynaklanan davalarda ${ }^{38}$, tüketici hukukundan kaynaklı davalarda ${ }^{39}$, kişilik haklarına saldırıdan kaynaklı tazminat davalarında ${ }^{40}$ yargılamanın daha kısa sürede sonuçlandırılmasında önemli bir kişisel yararın bulunduğuna hükmetmektedir.

\section{D- MAKUL SÜRENIN HESAPLANMASINDA ESAS ALINACAK TARİHLER}

\section{1-Ceza Davalarında}

Anayasa Mahkemesi ve AİHM kararlarına göre, ceza davalarında makul sürenin başlangıç tarihi, kişiye suç isnadının resmen bildirildiği tarih veya herhangi bir bildirim yoksa kişinin isnattan ilk olarak etkilendiği arama ve gözaltı gibi bir takım tedbirlerin uygulandığ 1 andır. Sürenin bitimi ise temyiz incelemesi de dâhil olmak üzere yargılamanın sona erdiği tarihtir ${ }^{41}$. Yargılamanın devam ettiği davalar açısından ise makul sürenin hesaplanmasında esas alınacak son tarih, Anayasa Mahkemesinin başvuru hakkında kararını verdiği tarihtir.

37 Çelik, s. 94; Nesrin Kılıç Başvurusu, AYM, Başvuru No: 2013/772, K.T. 07.11.2013. “...Makul sürede yargılanma hakkına ilişkin olarak yapılan değerlendirmede önemli bir ölçüt olan başvurucunun davanın hızla sonuçlandırılmasındaki menfaatinin niteliği kriteri çerçevesinde, gerek bireylerin ekonomik geleceği gerek çalışma barışı açısından arz ettiği önem nazara alındığında, iş uyuşmazlıklarının ivedilikle çözülmesi hususunda yargı organlarının özel bir itina göstermesi gerekmektedir. Bu nedenle kanun koyucu iş hukukunun çalışanı koruyucu niteliğini ve iş davalarının özelliklerini dikkate alarak genel mahkemelerin dışında sözlü yargılama usulüne tabi özel bir iş yargılaması sistemi ihdas ederek iş davalarının, konunun uzmanı mahkemelerce mümkün olduğunca hızlı, basit ve ucuz bir biçimde sonuçlandırılmasını amaçlamıștır..."<https://kararlarbilgibankasi.anayasa.gov.tr/> s.e.t. 05.03.2018. CCelik, s. 95.

39 Taylan Kamış Başvurusu, AYM, Başvuru No: 2013/5709, K.T. 17.03.2016. “...Adil yarg1lanma hakkı devlete, uyuşmazlıkların makul süre içinde sonuçlandırılmasını garanti edecek bir yargı sistemi kurma ödevi yükler. Tüketici mahkemesinde açılan alacak davasında derhâl bir yargı kararı verilmesinde, tüketici konumundaki başvurucunun önemli bir kişisel yararı bulunmaktadır. Bu nedenle tüketici mahkemelerinde görülen uyuşmazlıkların ivedilikle çözülmesi hususunda yargı organlarının özel bir itina göstermesi gerekir..." < https://kararlarbilgibankasi.anayasa.gov.tr/> s.e.t. 05.03.2018.

40 H.Ş. Başvurusu, AYM, Başvuru No: 2013/7123, K.T. 06.02.2014. “...Gazetede yapılan haberle kişilik haklarına saldırıda bulunulduğu iddiasını ileri süren bir kişinin, bu fiil sonucu ortaya çıkan zararının karşılanması için derhal bir yargı kararı verilmesinde önemli bir kişisel yararı bulunmaktadır..."<https://kararlarbilgibankasi.anayasa.gov.tr/> s.e.t. 05.03.2018.

41 Doğru/Nalbant, s. 634. ; Çelik, s. 101. 
Makul sürenin hesaplanmasındaki başlangıç tarihi 23.09.2012 tarihinden önce olan, ancak bu tarihte yargılaması devam eden veya verilen nihai karar henüz kesinleşmemiş olan ceza davaları ile ilgili olarak, dikkate alınacak süre, 23.09.2012 tarihinden sonra geçen süre değil, suçun isnat edildiği tarihten itibaren geçen süredir. Dolayısıyla, ceza muhakemesinde yargılama süresinin makul olmadığ yönündeki şikâyetlerde, 23.09.2012 tarihinde derdest olmak şartıyla, suç isnadının gerçekleştiği tarihten nihai kararın ilgilisi tarafından öğrenildiği tarihe veya devam eden davalarda Anayasa Mahkemesinin başvuruyu karara bağladığı tarihe kadar geçen süre dikkate alınacaktır ${ }^{42}$.

\section{2- Hukuk Davaları ve İdari Davalarda}

Medeni hak ve yükümlülüklerle ilgili yani hukuk ve idari yargı uyuşmazlıklarına ilişkin makul süre değerlendirmesinde, sürenin başlangıcı kural olarak davanın mahkemeye getirildiği tarihtir. Ancak bazı durumlarda bu süre daha önce de başlayabilir. Sürenin bitiş tarihi ise, çoğu zaman icra aşamasını da kapsayacak şekilde yargılamanın sona erme tarihidir ${ }^{43}$.

Her ne kadar medeni hak ve yükümlülüklerle ilgili uyuşmazlıklara ilişkin makul süre değerlendirmesinde, sürenin başlangıcı davanın ikame edildiği tarih ise de, bazı özel durumlarda uyuşmazlığın ortaya çıktığı önceki bir tarih de başlangıç tarihi olarak kabul edilebilmektedir ${ }^{44}$. Örneğin, park alanına dönüştürülen ancak uzun süredir kamulaştırılmayan taşınmazların kamulaştırılarak bedelinin ödenmesi, bunun mümkün olmaması durumunda ise belediyeye ait başka taşınmazlarla takas edilmesi veya imara açılması hususlarını içeren başvurucu taleplerini ilgili idarelere ilettiği tarih ${ }^{45}$; asli müdahale yoluyla davaya katılma durumunda asli müdahil yönünden müdahale tarihi ${ }^{46}$ başlangıç tarihi olarak esas alınacaktır.

\footnotetext{
42 B.E. Başvurusu, AYM, Başvuru No: 2012/625, K.T. 09.01.2014. <https://kararlarbilgi bankasi.anayasa.gov.tr/> s.e.t. 05.03.2018.

43 Doğru/Nalbant, s. 634.; Çelik, s.84; Tezcan/Erdem/Sancakdar, s. 200.

44 İnceoğlu, Adil Yargılanma Hakkı ve Yargı Etiği, s. 114.

45 Selahattin Akyıl Başvurusu, AYM, Başvuru No: 2012/1198, K.T. 07.11.2013

<https://kararlarbilgibankasi.anayasa.gov.tr/> s.e.t. 05.03.2018.

46 Haydar İzgi Başvurusu, AYM, Başvuru No: 2012/673 K.T. 07.11.2013. <https://kararlar bilgibankasi.anayasa.gov.tr/> s.e.t. 05.03.2018.
} 
Anayasa Mahkemesinin zaman bakımından yetkisinin başlangıç tarihi olan 23.09.2012 tarihinden önce açılmış ve bu tarih itibariyle derdest olan davalarla ilgili olarak yapılan makul sürede yargılanma hakkının ihlal edildiği iddiasını konu alan şikâyetlerde dikkate alınacak süre, belirtilen tarihten sonra geçen süre değil, uyuşmazlığın başlangıç tarihinden itibaren geçen süredir ${ }^{47}$.

Başvuruya konu davanın, başvurucunun miras bırakanından intikalle takip etmekte olduğu bir uyuşmazlık olması halinde, makul süre değerlendirmesi bakımından dikkate alınacak sürenin başlangıç anı, mirasçının yargılamaya katıldığı an değil, somut olayda muris açısından değerlendirmeye esas alınan sürenin başlangıç anıdır ${ }^{48}$.

\section{MAKUL SÜREDE YARGILANMA HAKKININ İHLALİ NEDENIYYL DEVLETIN SORUMLUĞUNUN NITELIĞİ}

\section{A- DEVLETİN SORUMLULUĞUNUN NITTELİĞİ}

Kamu görevlilerinin haksız işlem ve eylemlerden kaynaklanan zararların idarece tazmin edileceği, Anayasamızın 40, 125 ve 129 uncu maddelerinde düzenlenmiştir. Bu maddelerde açıkça düzenlenen sorumluluğun temel kaynağını ise Anayasamızın 2 nci maddesinde yer verilen hukuk devleti ilkesi oluşturmaktadir ${ }^{49}$.

Uygulamada devletin sorumluluğu, sadece idari makamların eylem ve işlemlerine hasredilmiştir. Oysaki yargısal faaliyetlerin de kişileri zarara uğratması mümkündür. Ayrıca hukuk devleti ilkesi devletin sadece idari faaliyetleri ile sınırlı olmayıp devletin tüm kamusal faaliyetleri açısından geçerli bir ilkedir. Bu nedenle kamusal bir faaliyet olduğunda şüphe bulunmayan yargisal faaliyetlerde de hukuk devleti ilkesi uyarınca devletin sorumluluğuna gidilmesi mümkündür. Hukukumuzda yargısal faaliyetlerin hukuka aykırı olup olmadığına, faaliyetin niteliği nazara alınarak AİHM, Anayasa Mahkemesi, kanun yolu incelemesi yapan üst yargı mercileri ve kanunlarla ayrıca görevlendirilen diğer yargı mercilerince karar verilmektedir.

47 Güher Ergun ve Diğerleri Başvurusu, AYM, Başvuru No: 2012/13, K.T. 02.07.2013. $<$ https://kararlarbilgibankasi.anayasa.gov.tr/> s.e.t. 05.03.2018

48 Gülseren Gürdal ve Diğerleri Başvurusu, AYM, Başvuru No: 2013/1115, K.T. 05.12.2013. $<$ https://kararlarbilgibankasi.anayasa.gov.tr/> s.e.t. 05.03.2018.

49 Muratoğlu, Tahir (2016) Devletin Yargısal Faaliyetlerden Kaynaklanan Sorumluluğu, 1. Baskı, Ankara, Seçkin Yayınevi, s. 324. 
Yargısal faaliyet ve kararlardan kaynaklanan maddi veya manevi nitelikteki zararların devletçe giderilmesi gerektiğine dair özel bir düzenlemeye ihtiyaç bulunmamaktadır ${ }^{50}$. Ancak hukuk sistemimizde özel düzenlemeye konu edilen haller de bulunmaktadır. CMK'nın 141 ila 144 üncü maddelerinde düzenlenen koruma tedbirleri nedeniyle tazminata dair hükümler, bu sorumluluğa açıkça yer veren tipik bir örnektir.

İnceleme konumuzu oluşturan makul sürede yargılanma hakkının ihlal edildiğine yönelik bireysel başvurular neticesinde Anayasa Mahkemesince verilecek ihlal ve tazminat kararları da devletin yargısal faaliyetlerinden kaynaklı sorumluluğunun diğer tipik bir örneğidir. Bu halde, zararın maddi ya da manevi nitelikte olması mümkündür. Ancak, makul sürede yargılanma hakkının ihlalinde meydana gelen zararın genel olarak manevi nitelikte olduğu söylenebilecektir. Mahkemece bu manevi zararın tazmini, isteme bağlı olarak, manevi tazminata hükmedilmesiyle sağlanmaktadır. Yüksek Mahkemece manevi tazminat miktarının belirlenmesinde de yargılamanın süresi, davanın türü ve davanın kısa sürede sonuçlandırılmasındaki taraf menfaatinin niteliği gibi ölçütlerden yola çıkılarak her başvuru kendi özelliklerine göre değerlendirilmektedir. Örneğin, 12 yıl altı 6 ay süren marka tescilinin iptali davası ile markaya vaki tecavüzün önlenmesi ve manevi tazminat istemli davada $19.600 \mathrm{TL}^{51}$; hakaret suçundan yapılan ve 5 yıl 7 ay süren ceza yargılaması nedeniyle $6.000 \mathrm{TL}^{52}: 11$ yıl 9 ay süren tapu iptali ve tescil davasında $10.000 \mathrm{TL}^{53}: 7$ yıl 3 ay süren ve atama işlemi nedeniyle açılan iptal ve tam yargı davasında 7.200 TL ${ }^{54}$ manevi tazminata hükmedilmiştir.

Makul süreyi aşan yargılamalarda, sunumu tamamen devlet tekelinde bulunan yargı hizmetlerinin geç işlemesi söz konusudur. Bu gecikme nedeniyle devletin sorumlu olup olmadığının belirlenmesinde AİHM ve Anayasa Mahkemesi tarafından geliştirilen davanın karmaşıklığı, başvurucunun tutumu, yetkili makamların tutumu ve yapısal sorunlar ile başvurucunun menfaatinin niteliği

\footnotetext{
50 Muratoğlu, s. 274.

51 Uğur Kiremit Sanayi Ticaret A.Ş. Başvurusu, AYM, Başvuru No: 2014/11576, K.T. 6.12.2017. $<$ https://kararlarbilgibankasi.anayasa.gov.tr/> s.e.t. 01.03.2018.

52 A.M.H. Başvurusu, AYM, Başvuru No: 2014/14028, K.T. 6.12.2017. $<$ https://kararlarbilgibankasi.anayasa.gov.tr/> s.e.t. 01.03.2018.

53 Vicdan Öksüz Başvurusu, AYM, Başvuru No: 2014/18140 K.T. 9.1.2018. $<$ https://kararlarbilgibankasi.anayasa.gov.tr/> s.e.t. 01.03.2018.

54 Hülya Çakalır Başvurusu, AYM, Başvuru No: 2014/8886 K.T. 5.10.2017. $<$ https://kararlarbilgibankasi.anayasa.gov.tr/> s.e.t. 05.03.2018.
} 
ölçütleri kullanılacaktır. Bu ölçütlerin, idare hukukunda hizmet kusurunun tespitinde dikkate alınacak kusurlu eylem, zarar ve illiyet bağ liştirildiği kanaatindeyiz.

\section{B- DEVLETIN SORUMLULUĞUNUN ISTTISNALARI VE 15 TEMMUZ DARBE GIRIŞIMININ MAKUL SÜREDE YARGILANMA HAKKINA ETKISİ}

İdare hukukunda devletin sorumluluğunu azaltan ya da ortadan kaldıran haller olarak kabul edilen, mücbir sebep, beklenmeyen hal, zarar görenin ya da üçüncü kişinin davranışı da niteliğine uygun düştüğü ölçüde makul sürede yargılanma hakkının ihlalinden kaynaklı sorumluluk hallerinde işlerlik kazanabilecektir. Anayasa Mahkemesi ve AİHM'nin içtihatlarında makul süre aşılmasına rağmen devletin sorumluluğuna gidilmeyen haller incelendiğinde idare hukukunda da geçerli olan benzer sebeplere işaret edildiği görülmektedir.

Anayasa Mahkemesi kararlarında yargılamanın uzun sürmesine rağmen devletin sorumluluğuna gidilmeyen en tipik hal, yargılamanın başvurucunun kusurundan kaynaklanan nedenlerle uzamasıdır. Başvurucunun yargılama sürecindeki kusur ya da ihmalleri nedeniyle meydana gelen zarar ile yargısal faaliyet arasındaki illiyet bağı ortadan kalkacak, yargılama süresinin uzaması başvurucunun bu olumsuz tutumunun neticesi olarak kabul edilecektir.

Meydana gelen deprem, sel gibi mücbir sebepler nedeniyle yargilamalarda oluşabilecek gecikmelerin de makul süre değerlendirmesinde dikkate alınması gereklidir. Örneğin, Van ilimizde meydana gelen deprem nedeniyle yargılamalar az sayıda yargı mensubu ve diğer personel tarafından ciddi fiziki yoksunluklar içerisinde neticelendirilmeye çalışılmıştır. Yine üçüncü kişinin davranışından kaynaklı gecikmelerin de somut olaya göre devletin sorumluluğunu engellemesi veya azaltması da mümkündür.

Ulusal yargılama mercilerinin iş yükünde tahmin edilemeyen krize dayalı geçici bir yoğunluk olması halinde; yetkili makamların sorunun farkında olup, onu çözmek için yeterli çabayı göstermesi şartıyla, AİHM tarafindan, makul sürede yargılanma hakkının ihlal edilmediği yönünde karar verilebilmektedir $^{55}$. AİHM, Buchholz/Federal Almanya kararında, 1970’lerin ortasında büyük ekonomik bunalımdan kaynaklanan ve makul olarak öngörülemeyecek nitelikteki dava yığılması nedeniyle oluşan gecikmede, devletin yargıç sayısını da artırarak sorunu çözmeye çabalamasını dikkate almış ve makul sürede yargılanma

55 İnceoğlu, s. 282. 
hakkının ihlal edilmediğine hükmetmiştir. Benzer şekilde Foti ve diğerleri/İtalya kararında da büyük çaplı kamusal eylemlerden kaynaklı çok sayıda soruşturma yapılmasının yol açtığ geçici bir iş yükünden kaynaklı gecikmeyi makul görmüştür ${ }^{56}$. Papageorgiou/Yunanistan davasında ise baro üyelerinin grevde olması nedeniyle yargılamaların uzamasında sorumluluğu doğrudan devlete yükletmemiş, devletin ortaya çıan gecikmeleri azaltmaktaki çabalarının dikkate alınacağına karar vermiştir ${ }^{57}$.

AİHM’nin anılan içtihatlarından yola çıkılarak 15 Temmuz darbe girişiminin de bu kapsamda kalıp kalmayacağı değerlendirilmelidir. 15 Temmuz darbe girişimi, Anayasa Mahkemesi, Yargıtay Ceza Genel Kurulu, Yargıtay 16 ncı Ceza Dairesi ve bölge adliye mahkemeleri ile çok sayıda ilk derece mahkemesi kararına konu edilmiştir.

Yargıtay 16 ncı Ceza Dairesi içtihatlarında 15 Temmuz'da gerçekleştirilen silahlı darbe teşebbüsü ile ilgili olarak ülke genelindeki olayların saat saat özeti yapılmakta ve 15 Temmuz darbe teşebbüsü ve FETÖ(Fetullahçı Terör Örgütü)/PDY(Paralel Devlet Yapılanması) silahlı terör örgütü ilişkisi açılanmak$\operatorname{tad}_{10}{ }^{58}$.

Hâkimler ve Savcılar Kurulunca 2016 ve 2017 yılları içinde verilen çok sayıda meslekten çıkarma kararında da FETÖ/PDY’nin kuruluşu, örgütlenmesi ve bilhassa yargı alanındaki yapılanması ile gerçekleştirdiği faaliyetler üzerinde ayrıntılı bir şekilde durulmaktadır ${ }^{59}$. Öncelikle bu kararlardan bir kısmını inceleyerek yargının konuya bakışının gözlemlenmesi gerektiği kanaatindeyiz.

56 Harris, D.J/ O’Boyle, M./Bates, E.P./Buckley, C.M. (2009) Avrupa İnsan Hakları Sözleşmesi Hukuku, Ankara, Şen Matbaa, s. 286.

57 Avrupa İnsan Hakları Mahkemesi 6. Madde Rehberi Adil Yargılanma Hakkı(Medeni Hukuk Yönü), s.52. <https://www.echr.coe.int/Documents/Guide_Art_6_TUR.pdf> s.e.t. 26.09.2018.

$58 \quad$ Yargitay 16. Ceza Dairesi E: 2017/1443, K: 2017/4758, T: 14.07.2017. <https://emsal.yargitay.gov.tr/BilgiBankasiIstemciWeb/GelismisDokumanAraServlet> s.e.t. 02.05.2018.

59 Hâkimler ve Savcılar Kurulu Genel Kurulunun 05.10.2017 Tarih ve 2017/770 Karar Sayılı Kararı İle Meslekten Çıkarılmalarına Karar Verilen Hâkim ve Cumhuriyet Savcılarına İlişkin Gerekçeli Karar ve Liste,

<http://www.hsk.gov.tr/Eklentiler/Dosyalar/karar06-10-2017.pdf> benzer nitelikteki kararlar için bakınız: http://www.hsk.gov.tr/DuyuruArsivi.aspx) s.e.t. 02.05.2018. 
Anayasa Mahkemesi, Aydın Yavuz ve Diğerleri başvurusunda ${ }^{60}$ tutukluluk durumunun 8 ay 18 gün duruşma yapılmaksızın dosya üzerinden değerlendirilmesini olağanüstü şartların gerektirdiği ölçüde bir tedbir olarak kabul etmiştir. Bu karar, darbe teşebbüsü ve süreci ve darbe teşebbüsünün arkasındaki yapılanma olan FETÖ/PDY hakkında önemli tespitlere yer vermesi itibarıyla oldukça önemlidir. Bu nedenle, Anayasa Mahkemesinin sonraki kararlarında da esas aldığ 1 bu karara, incelememizde ayrıntılı olarak yer verilmesi isabetli olacaktır.

Darbe girişiminin arkasında FETÖ/PDY'nin olduğu tespitine de yer verilen mezkûr kararda darbe girişiminin amacı ve boyutu özetle şu şekilde açılanmaktadır: "...Darbe teşebbüsünde bulunanlarca hazırlanan "sıkıyönetim direktifi" ile Türk Silahl Kuvvetleri (TSK) tarafından emir komuta bütünlüğ̈̈ içinde devletin yönetimi maksadıyla "Yurtta Sulh Konseyi" teşkil edildiği, yönetime el konulduğu, tüm yurtta sıkıyönetim ve sokağa çıkma yasağı ilan edildiği, kamu yetkisi ile yapılan tüm atama ve görevlendirmelerin teşkil edilen "Yurtta Sulh Konseyi" tarafindan veya onun vereceği yetkiye istinaden yapılacağı, bunun haricinde yapılacak işlemlerin yok hükmünde olduğu, mevcut yürütme erkinin görevden el çektirildiği, Türkiye Büyük Millet Meclisinin (TBMM) feshedildiği, tüm valilerin görevden alındı̆̆l, tüm vali, kaymakam ve belediye başkanlı̆̆ atamalarının "Yurtta Sulh Konseyi" tarafından yapılacağl, siyasi partilerin tüm faaliyetlerinin sonlandırıldiğl, polis teşkilatının sıkıyönetim komutanları emrine alındığı belirtilmiştir. Anılan direktifin ve ekindeki sıkıyönetim komutanlıklarına ilişkin atama listesinin, darbe teşebbüsünde bulunanlar tarafindan ilgili askerî birimlere ve bakanlıklara gönderildiği anlaşılmıştır.

Darbe teşebbüsü sırasında TBMM, Cumhurbaşkanlığı Külliyesi, Ankara Emniyet Müdürlüğ̈̈, Emniyet Genel Müdürlüğ̈̈ Özel Harekât Daire Başkanlığı, Millî İstihbarat Teşkilatı (MİT) yerleşkelerinin de aralarında bulunduğu birçok yere uçak ve helikopterlerin de kullanıldı̆̆ bombalı ve silahlı saldırılar yapılmıştır. Öte yandan Cumhurbaşkanı'nın konakladığı otele silahlı baskın yapılmış ancak Cumhurbaşkanı kısa süre önce otelden ayrıldığı için baskın amacına ulaşamamıştır. Ayrıca Başbakan'ın aracının bulunduğu konvoya silahla ateş edilmiş, Genelkurmay Başkanı ve kuvvet komutanlarının da aralarında bulunduğu birçok üst düzey askerî yetkili rehin alınmıştır. Yine Avrupa ve Asya'yı birbirine bağlayan Boğaz köprüleri ile İstanbul'da bulunan havalimanları tanklar ve zırhlı

60 Aydın Yavuz Başvurusu, AYM, Başvuru No: 2016/22169 K.T. 20.6.2017.

< https://kararlarbilgibankasi.anayasa.gov.tr/BB/2016/22169> s.e.t. 02.05.2018. 
araçlar marifetiyle ulaşıma kapatılmış, ülkenin birçok yerindeki çok sayıda kamu kurumu silah zoruyla işgal edilmiş veya buna teşebbüs edilmiştir.

Genelkurmay Başkanlığı tarafindan yapılan açıklamada; ilk belirlemelere göre anılan teşebbüse 8.000'in üzerinde askerî personelin karıştı̆̆ı, teşebbüs sırasinda savaş uçakları dâhil 35 uçağın, 3 geminin, 37 helikopterin, 74 tanesi tank olmak üzere 246 zırhlı aracın ve 4.000'e yakın hafif silahın kullanıldığı bilgisine yer verilmiştir.

Darbe teşebbüsüne karşı koyan güvenlik görevlileri ile tepki göstermek üzere sokaklara çıkan sivillere uçaklar, helikopterler, tanklar, diğer zırhlı araçlar ve silahlarla saldırılmış; bu saldırılar sonucunda 4'ü asker, 63'ü polis ve 183'ü sivil olmak üzere toplam 250 kişi hayatını kaybetmiş; 23'ü asker, 154'ü polis ve 2.558'i sivil olmak üzere toplam 2.735 kişi yaralanmıştır. Başbakan; darbecilerden 36'sının öldü̆̆̈̈nü, 49'unun yaralandı̆̆ını açıklamıştır...”

Mezkur kararda yer verilen “Adalet Bakanlığı verilerine göre FETÖ/PDY soruşturmaları kapsamında 13/6/2017 tarihi itibarıyla hakkında soruşturma yürütülen kişi sayısı 161.785'dir. Bu kişilerden 47.136'sı adli kontrol tedbiri uygulanarak, 13.497'si ise herhangi bir koruma tedbiri uygulanmaksızin serbest birakılmıştır. Yine haklarında soruşturma yürütülen 30.597 kişi hakkında yakalama ve gözaltı gibi adli bir işlem yapılmamıştır. Hakkında tutuklama tedbiri uygulanan 50.436 kişiden 2'si Anayasa Mahkemesi üyesi, 104'ü Yargıtay üyesi, 41'i Danıştay üyesi, 3'ü HSYK üyesi, 2.492'si hâkim ve savcl, 7.143'ü asker (169'u general/amiral), 8.849'u polis, 24'ü vali, 73'ü vali yardımcısı ve 115'i kaymakamdır. Öte yandan 8.359 kişi (bunlardan 8'i Yargıtay üyesi, biri Danıştay üyesi, 2'si HSYK üyesi, 208'i hâkim ve savcı, 1.332'si asker, 1.336'sl polis, 3'ü vali, 9'u vali yardımcısı, 4'ü kaymakamdır) tutuklama tedbiri uygulandıktan bir süre sonra tahliye edilmiştir. Tahliye edilen bu kişilerin 7.969'u hakkında adli kontrol tedbirleri uygulanmıştır. Diğer taraftan kaçak durumda olup haklarında soruşturma/kovuşturma mercilerince yakalama emri çıkarılan 7.605 kişiden 26 's Yargıtay üyesi, 6'sı Danıştay üyesi, 218'i hâkim ve savcı, 147'si asker, 386'sı polis, 3'ü vali yardımcısı ve 9'u kaymakamdır. 790 kişi hakkında ise gözaltı sürecinin devam ettiği anlaşılmıştır.. Soruşturma mercileri darbe teşebbüsü gibi ani gelişen bir durum üzerine bir anda on binlerce şüpheli hakkında soruşturma başlatma ve yürütme zorunluluğu ile karşı karşıya kalmıştır. Teşebbüsün faili olduğu değerlendirilen FETÖ/PDY'nin özellikleri (gizlilik, hücre tipi yapılanma, her kurumda örgütlenmiş olma, kendisine kutsallik atfetme, itaat ve teslimiyet temelinde hareket etme gibi) de dikkate alındiğında bu soruşturmaların diğer 
ceza soruşturmalarına göre çok daha zor ve karmaşık olduğu ortadadır. Bu bağlamda bilhassa yargı organları ve soruşturma mercileri, öngörülemez şekilde ağır bir iş yükünü yönetmek zorunda kalmışlardır..." tespitleri ile yargının artan iş yüküne,

“...Başta Anayasa Mahkemesi ve HSYK olmak üzere sinırl sayıda kamu kurum ve kuruluşu idari bir kararla mensuplarını meslekten veya kamu görevinden çıkarmıştır. Bu kapsamda aralarında yüksek mahkeme üyelerinin de bulunduğu 4.000'in üzerinde yargı mensubu meslekten çıkarılmıştır. Öte yandan 668, 669, 670, 672, 675, 677, 679, 683, 686, 689 sayılı KHK'lar ile yaklaşık 98.500 kamu görevlisi kamu görevinden çıkarılmıştır. Bu kapsamda TSK'nın general/amiral kadrosunun yarısına yakınının kamu görevinden çıkarıldı̆̆ görülmektedir. Bunun dişında TSK'da, mülki idarede, emniyet teşkilatında, üniversitelerde ve diğer kamu kurumlarında görev yapan çok sayıda kişi kamu görevinden çıkarılmıştır. Kamu görevinden çıkarılan kişiler arasında sayısal bakımdan ilk sırada ögretmenler bulunmaktadır...." tespitleriyle de meslekten çıkarılan kamu görevlilerinin sayısına dikkat çekilmektedir. Kararda, darbe girişimine dair Avrupa Konseyi İnsan Hakları Komitesinin Memorandumu(CommDH (2016)35)'na ve Venedik Komisyonu(Görüş No:865/2016) raporuna da atıfta bulunulmaktadır.

Aydın Yavuz ve diğerleri başvurusunda yer verilen tespitlerin benzerlerine, aynı taleplerin değerlendirildiği Erdal Tercan başvurusunda da yer verilmektedir. Anayasa Mahkemesi, aynı zamanda eski üyesi olan Erdal Tercan hakkındaki 1 yıl 9 aylık tutukluluk süresini makul bulurken, başvurucunun 21 ay süreyle hâkim önüne çıkarılmaksızın hakkındaki tutukluluk kararının dosya üzerinden değerlendirilmesinin kişi hürriyet ve güvenliği hakkının ihlali olduğuna karar vermiştir. Bu ihlal kararının gerekçesinde özetle: “...Olağanüstü hal sürecinde...mevcut hakim ve savcı adaylarının stajlart sonlandırlarak hemen mesleğe başlamaları sağlanmış, ayrıca çok sayıda yeni hakim ve savcı adayı alımına yönelik idari süreç başlatılmış ve adayların staj süreleri kısaltılmış, yine emekli olan veya istifa eden hakim ve savcıların mesleğe dönmelerine imkan tanınmıştır. Bu tedbirler sonucunda darbe teşebbüsü sonrası süreçte yaklaşık altı bin hakim ve savcı göreve başlamış, böylelikle hakim ve savcı sayısında önemli bir artış sağlanmak suretiyle olağanüstü hal döneminde hakim ve savcıların meslekten çıkarılmasından kaynaklanan açık kapatılmıştır. ...darbe teşebbüsü ve FETÖ/PDY ile bağlantıl soruşturma ve kovuşturma süreçlerindeki ilerlemelere 
ilişkin süreçlerin aşamaları başta olmak üzere olağanüstü hal sürecindeki gelişmeler birlikte dikkate alındiğında özellikle darbe teşebbüsü, FETÖ/PDY ve terörle ilgili olarak yürütülen soruşturma ve/veya kovuşturmalarda tutukluluk incelemelerinin hâkim/mahkeme önüne çıkarılmaksızın yapılmasının ve tutukluluğun dosya üzerinden verilen kararlarla devam ettirilmesinin on sekiz aya kadar "durumun gerektirdiği ölçüde" bir tedbir olarak kabul edilebileceği değerlendirilmiştir... Anayasa Mahkemesi; her bir başvuruda somut olayın koşullarını, tutukluluk incelemelerinin duruşmasız olarak yapıldığı süreyi ve olağanüstü hal döneminde bu süre içindeki yaşanan gelişmeleri dikkate alarak bir değerlendirme yapacaktır... Başvurucunun tutukluluk incelemeleri kapsamında on sekiz ayı aşan bir süre boyunca hakim/mahkeme önüne çıkarılmaması ve tutukluluğa ÿ̈nelik itirazlarını, tutuklamaya dayanak olan delillerin içeriğine veya nitelendirilmesine yönelik iddiaların, lehine ve aleyhine olan görüşve değerlendirmelere karşı beyanlarını, tahliye taleplerini hakim/mahkeme önünde sözlü olarak dile getirmesine imkan tanınmaması "durumun gerektirdiği ölçüde" bir tedbir olarak değerlendirilmemiştir..." açıklamalarına yer verilmektedir. Kararın karşı oy gerekçesinde ise "olağanüstü hal süresince hakim ve savcı sayısının artırılmasına yönelik olarak bazı tedbirler alınmış ise de, tutukluluk incelemelerinin hakim/mahkeme huzuruna çıkarılarak yapılması işi, sadece hakim ve savcı sayısı ile ilgili olmayıp, konunun başta güvenlik sorunu olmak üzere, hakim savcı sayısı artırılmış olmakla birlikte dava ve uyuşmazlık sayısının da arttığı, tutukluların kaldıkları ceza ve tutukevlerinden mahkemelere getirilip götürülmelerinde görev alacak araç ve personel imkanları ile belirtilen kapsamdaki tutuklu sayısının fazlalı̆̆ı gibi başkaca boyutları ve etkileyenleri de bulunmaktadır. Ayrıca, darbe teşebbüsüne ilişkin davaların büyük bir bölümünün ilk derece mahkemelerinde devam ediyor olması, FETÖ/PDY ile bağlantılı suçlardan yapılan soruşturma ve kovuşturmaların çoğunun derdest olması, olağanüstü halin ilk ilan edildiği dönemi izleyen dönemlerdeki koşulların ortadan kalkmadiğına işaret etmektedir" görüşü savunulmuştur.

Anayasa Mahkemesinin Aydın Yavuz ve diğerleri kararı başvurusu ile Erdal Tercan başvurusunda verdiği iki kararda da gerçekleşen darbe girişiminin temel hak ve hürriyetlerin sınırlandırılması üzerindeki olumsuz etkisi gözetilmiştir. Ancak, Erdal Tercan başvurusunda darbe teşebbüsü üzerinden geçen süre, yargı mercilerindeki eksikliklerin giderilmesi gibi hususlar da gözetilerek objektif ölçütler belirlenmeye çalışılmaktadır. Bu kararlarda geçen ölçütler inceleme konumuz olan makul sürede yargılanma hakkı açısından da önemlidir. 
Bu çerçevede Adalet Bakanlığı istatistikleri incelendiğinde 2015 yllında 10.382 olan toplam hâkim ve Cumhuriyet savcısı sayısının 2016 yılında 11.372, 2017 yılında ise 11.530 olduğu görülmektedir. Yine, 2015 yılında 60.388 olan toplam personel sayısı 2016 yılında 56.571'e düşmüş ancak 2017 yılında tekrar 60.847'e yükseltilmiştir ${ }^{61}$. Bu anlamda darbe teşebbüsünün yol açtığı insan kaynağ1 eksiğinin giderildiğinin kabulü isabetli olacaktır.

Adalet Bakanlığınca, darbe teşebbüsünden sonraki süreçte, makul sürede yargılanma hakkının sağlanmasına yönelik gerçekleştirilen bir diğer faaliyet de Soruşturma, Kovuşturma veya Yargılama Hedef Sürelerinin Belirlenmesi ve Uygulanmasına İlişkin Yönetmelik düzenlemesidir. 01.09.2017 tarihinde yürürlüğe giren bu Yönetmelikle, soruşturma veya kovuşturma ya da yargılamaların tamamlanması için öngörülen hedef sürelerin belirlenmesi ve uygulanmasına dair usul ve esaslar tespit edilmiştir. Yönetmelikte hedef süre "soruşturma, kovuşturma veya yargilamaların tamamlanmasında gözetilen, ilgilileri için hak doğurmayan, yargisal süreçleri iyileştirmeyi amaçlayan ve Kurul'un görüşü alınarak Bakanlık tarafindan belirlenen süre" olarak tanımlanmış ve bu süreye riayet edilip edilmediği hususunun hâkim ve Cumhuriyet savcıları hakkında düzenlenecek kanun yolu değerlendirme formlarında dikkate alınacağı belirtilmiştir. Ayrıca Yönetmeliğin 8 inci maddesin uyarınca, hedeflenen sürede sonuçlanmayan her bir dava ve soruşturma dosyasına ilişkin gecikme nedenleri, dosyayı muktezaya bağlayan başkan, üye, hâkim veya Cumhuriyet savcısı tarafından UYAP'ta ilgili ekrana işlenecektir.

AİHM ve Anayasa Mahkemesinin hak ihlali iddialarını reddettiği anılan içtihatlarından yola çıkıldığında kanaatimizce, 15 Temmuz darbe ve işgal girişiminden kaynaklı çok sayıda soruşturma ve kovuşturma yapılması ve çok sayıda yargı mensubunun görevine son verilmesi nedeniyle tüm yargılamalarda oluşabilecek kısmi nitelikteki muhtemel gecikmelerin olağan görülmesi gerekmektedir. Ayrıca, Anayasal düzene ve bu düzenin işleyişine karşı işlenen suçlar ve silahlı terör örgütü üyeliği gibi suçlara ilişkin davaların oldukça karmaşık nitelikte olmaları da nazara alınarak darbe girişiminin olumsuz etkisi bu davalar açısından evleviyetle gözetilmelidir. Devletin ihraç edilen hâkim ve Cumhuriyet savcısı ile sair personelin yerine yeni istihdam sağlaması ile yargılamaların daha hızla sonuçlanması için çabalaması nazara alınarak yükümlülüğünü yerine getirdiği kabul edilmelidir.

${ }^{61}$ Adalet Bakanlığı Adli Sicil ve İstatistik Genel Müdürlüğü Adli İstatistikler 2017

$<$ http://www.adlisicil.adalet.gov.tr/istatistik_2017/istatistik2017.pdf> s.e.t. 02.05.2018. 


\section{SONUÇ}

Kişilerin tarafı oldukları yargılama neticesinde verilecek kararın adil olması kadar yargılamanın zamanında neticelendirilmesi de önemlidir. AİHS, Anayasamız ve bazı kanunlarımızda açıkça düzenlenen makul sürede yargılanma hakkı, "geciken adalet, adalet değildir" șeklindeki veciz ilkenin normlara yansımış halidir.

AİHM içtihatlarına da yansıdığı üzere yargılamaların makul sürede neticelendirilmemesi sadece ülkemizin değil, çok sayıda devletin sorunudur. Ülkemizde bu sorunun yıllardır devam etmesi onu toplumsal bir sorun haline de dönüştürmüştür. Rahmetli Şair Abdurrahim Karakoç’un 1970 yılında söylediği ve zihinlere kazınan "bu dava dedemden kaldı hâkim beğ" dizesine konu yargılamaların sayısı azalsa da halen bitirilebilmiş değildir.

2010 yılında yapılan Anayasa değişikliği ile hukukumuza giren bireysel başvuru imkânı, uzun süren yargılamalar neticesinde adil yargılanma hakkı ihlal edilen kişiler için AİHM nezdinde etkili bir iç hukuk yolu olmuştur. Yüksek Mahkeme, başvuruları kabul etmeye başladığı 23.09.2012 tarihinden bu yana makul sürede yargılanma hakkı açısından çok sayıda karar vererek içtihat oluşturmuş̧tur. Bu kararlarda, AİHM'nin yerleşmiş içtihatlarından istifade edildiği görülmektedir.

Mahkemenin bireysel başvurulara dair kabul edilebilirlik incelemesinde geliştirdiği genel ölçütler, niteliğine uygun düştüğü ölçüde makul sürede yarg1lanma hakkına ilişkin başvurularda da geçerlidir. Mahkeme, makul sürenin değerlendirilmesi açısından da AİHM içtihatlarına uyumlu ölçütler kullanmaktadır. Davanın karmaşıklığı, tarafların ve yetkili makamların tutumu ve başvurucunun davanın hızla sonuçlandırılmasındaki menfaatinin niteliği olarak sayılabilecek bu ölçütleri her somut olaya ayrı ayrı uygulayarak makul süre tespiti yapan mahkeme, ihlal kararı verdiğinde talep bulunması halinde manevi tazminata da hükmetmektedir. Tazminat miktarının belirlenmesinde davanın niteliği, geçen süre, taraf sayısı gibi ölçütlerin esas alındığı anlaşılmaktadır.

Yargisal faaliyetlerin makul sürede bitirilememesi sebebiyle tazminata hükmedilmesi, devletin yargısal faaliyetler nedeniyle sorumlu tutulmasının tipik bir örneğidir. Anayasamızdaki güçler ayrılığı ve yargı bağımsızlı̆̆ı ilkesinin varlığının bu sorumluğa engel olmadığı, Anayasa Mahkemesi kararı uyarınca kişilerin mağduriyetlerinin devletçe karşılanacak olmasının bu ilkelerin ihlali anlamına gelmeyeceği, bilakis bu tazminin adil yargılanma hakkının korunmasına hizmet edeceği kanaatindeyiz. 
Çalışmamızın ilgili bölümünde değinildiği üzere Anayasa Mahkemesince makul sürede yargılanma hakkının ihlali yönünde verilen karar sayısı oldukça fazladır. Bu ihlal kararlarında devlet, yargı hizmetinin geç işlemesi nedeniyle sorumlu tutulmaktadır. Manevi tazminat olarak belirlenen bu sorumlulukla kişilerin uğradıkları zarar kısmen giderilmeye çalışılsa da asıl olan hakkın hiç ihlal edilmemesidir. Bu nedenle yargının kökleşmiş sorunlarına çözüm bulunması gereklidir.

Anayasa Mahkemesi ve AİHM’nin içtihatları incelendiğinde mücbir sebep, beklenmeyen hal, zarar görenin ya da üçüncü kişinin davranışından kaynaklı bazı hallerde makul süre aşılmasına rağmen devletin sorumluluğuna gidilmediği anlaşılmaktadır. Bu kapsamda bilhassa 15 Temmuz'da yaşanılan darbe teşebbüsü nedeniyle yargının artan iş yükü karşısında devletçe gerekli tedbirlerin de alındığı gözetildiğinde, Yüksek Mahkeme ve Adalet Bakanlığı İnsan Hakları Tazminat Komisyonunca bu olağanüstü durumun makul sürenin tespitinde dikkate alınması gerektiğini değerlendirmekteyiz. 


\section{KAYNAKÇA}

Başar, Mükerrem Onur (2011) Avrupa İnsan Hakları Kararları Çerçevesinde Makul Sürede Yargılanma Hakkı, İstanbul, On İki Levha Yayınları.

Çelik, Abdullah (2014) Adil Yargılanma Hakkı Rehberi, Ankara, Anayasa Mahkemesi Yayınları.

Doğru, Osman (2012) Anayasa Mahkemesine Bireysel Başvuru Rehberi, İstanbul, Legal Yayıncilık.

Doğru, Osman/Nalbant, Atilla (2012) İnsan Hakları Avrupa Sözleşmesi (Açılama ve Önemli Kararlar), Ankara, Şen Matbaa.

Gözübüyük, Şeref/Gölcüklü, Feyyaz (2011) Avrupa İnsan Hakları Sözleşmesi ve Uygulaması, 9. Bası, Ankara, Turhan Kitabevi.

Harris, D.J/O’Boyle, M./Bates, E.P./Buckley, C.M.(Çevirenler: Bingöllü Kılcı, Mehveş/Karan, Ulaş) (2009) Avrupa İnsan Hakları Sözleşmesi Hukuku, Ankara, Şen Matbaa.

İnceoğlu, Sibel (2007) Adil Yargılanma Hakkı ve Yargı Etiği, 1. Baskı, Ankara, Şen Matbaa.

İnceoğlu, Sibel (2013) İnsan Hakları Avrupa Sözleşmesi ve Anayasa(Anayasa Mahkemesine Bireysel Başvuru Kapsamında Bir İnceleme), Ankara, Şen Matbaa.

Koç, Muharrem İlhan/Kaplan, Recep (Editör) (2017) Bireysel Başvuru Kabul Edilebilirlik Kriterleri Rehberi, Ankara, Anayasa Mahkemesi Yayınları.

Muratoğlu, Tahir (2016) Devletin Yargısal Faaliyetlerden Kaynaklanan Sorumluluğu, Ankara, Seçkin Yayınevi.

Tezcan, Durmuş/Erdem, Mustafa Ruhan/Sancakdar, Oğuz (2004) Avrupa İnsan Hakları Sözleşmesi ve Uygulaması, Ankara, Adalet Bakanlığı Eğitim Dairesi Başkanlı̆̆ı.

Turan, Hüseyin (2012) "Avrupa İnsan Hakları Mahkemesi İçtihatlarında Makul Sürede Yargılanma Hakkı” Türkiye Adalet Akademisi Dergisi, Yll:3, S:11, s.47-75.

Turan, Hüseyin/Kaplan, Recep (Editör) (2015) Anayasa Mahkemesine Bireysel Başvuru ve Kabul Edilebilirlik Kriterleri,1. Baskı, Ankara, Anayasa Mahkemesi Yayınları. 
Adalet Bakanlığı Adli Sicil ve İstatistik Genel Müdürlüğü Adli İstatistikler 2017 <http://www.adlisicil.adalet.gov.tr/istatistik_2017/istatistik2017.pdf> s.e.t. 02.05.2018.

Avrupa İnsan Hakları Mahkemesi 6. Madde Rehberi Adil Yargılanma Hakkı(Medeni Hukuk Yönü), <https:/www.echr.coe.int/Documents/Guide_Art_ 6_TUR.pdf $>$ s.e.t. 26.09.2018.

Hâkimler ve Savcılar Kurulu Genel Kurulunun 05/10/2017 Tarih ve 2017/770 Karar Sayılı Kararı İle Meslekten Çıkarılmalarına Karar Verilen Hâkim ve Cumhuriyet Savcılarına İlişkin Gerekçeli Karar ve Liste $<$ http://www.hsk.gov.

tr/Eklentiler/Dosyalar/karar06-10-2017.pdf> s.e.t. 02.05.2018.

$<$ http://www.anayasa.gov.tr/icsayfalar/istatistikler/pdf/istatistik30Haziran.pd> s.e.t.26.09.2018. 
- 256 - 